\title{
Agronomic improvements can make future cereal systems in South Asia far more productive and result in a lower environmental footprint
}

\begin{abstract}
JAGDish KUMAR LADHA ${ }^{1}$, ADUSUMILLI NARAYANARAO ${ }^{1}$, ANiTHA K. RAMAN ${ }^{1}$, AGNES TIROL PADRE ${ }^{2}$, ACHIM DOBERMANN ${ }^{3}$, MAHESH GATHALA ${ }^{4}$, VIRENDER KUMAR ${ }^{2}$, YASHPAL SAHARAWAT ${ }^{5}$, SHEETAL SHARMA ${ }^{1}$, HANS PETER PIEPHO ${ }^{6}$, MD $^{\circ}$ MURSEDULALAM ${ }^{7}$, RANJAN LIAK ${ }^{8}$, RAMASAMY RAJENDRAN ${ }^{9}$, CHINNAGANGANNAGARI KESAVA REDDY ${ }^{1}$, RAJENDER PARSAD ${ }^{10}$, PARBODH C. SHARMA ${ }^{11}$, SATI SHANKAR SINGH ${ }^{12}$, ABHIJIT SAHA ${ }^{13}$ and SHAMSOON NOOR ${ }^{14}$

${ }^{1}$ IRRI (International Rice Research Institute), 1st Floor, CG Block, NASC Complex, DPS Marg, Pusa, New Delhi 110 012, India, ${ }^{2}$ IRRI, DAPO Box 7777, Metro Manila 1301, Philippines, ${ }^{3}$ Rothamsted Research, Harpenden, Hertfordshire AL5 2JQ, UK, ${ }^{4}$ CIMMYT (International Maize and Wheat Improvement Center), Dhaka Office, Dhaka, Bangladesh, ${ }^{5}$ Indian Agricultural Research Institute, Pusa Campus, New Delhi 110 012, India, 'Bostatistics Unit, Universitaet Hohenheim, 70593 Stuttgart, Germany, ${ }^{7}$ IRRI, Bangladesh Office, House-9, Road 2/2, Banani, Dhaka 1213, Bangladesh, ${ }^{8}$ Rajendra Agricultural University, Pusa, Samastipur, Bihar 848 125, India, ${ }^{9}$ Tamil Nadu Rice Research Institute, Aduthurai, Thanjavur 612 101,Tamil Nadu, India, ${ }^{10}$ Indian Agriculture Statistical Research Institute, Library Avenue, Pusa, New Delhi 110 012, India, ${ }^{11}$ Central Soil Salinity Research Institute, Zarifa Farm, Kachhwa Road, Karnal, 132001 Haryana, India, ${ }^{12}$ ICAR Parisar, P.O. Bihar Veterinary College, ICAR Research Complex for Eastern Region, Patna, 800014 Bihar, India, ${ }^{13}$ Bangladesh Rice Research Institute, Gazipur 1701, Bangladesh, ${ }^{14}$ Bangladesh Agricultural Research Institute, Gazipur 1701, Bangladesh
\end{abstract}

\begin{abstract}
South Asian countries will have to double their food production by 2050 while using resources more efficiently and minimizing environmental problems. Transformative management approaches and technology solutions will be required in the major grain-producing areas that provide the basis for future food and nutrition security. This study was conducted in four locations representing major food production systems of densely populated regions of South Asia. Novel production-scale research platforms were established to assess and optimize three futuristic cropping systems and management scenarios (S2, S3, S4) in comparison with current management (S1). With best agronomic management practices (BMPs), including conservation agriculture (CA) and cropping system diversification, the productivity of rice- and wheat-based cropping systems of South Asia increased substantially, whereas the global warming potential intensity (GWPi) decreased. Positive economic returns and less use of water, labor, nitrogen, and fossil fuel energy per unit food produced were achieved. In comparison with S1, S4, in which BMPs, CA and crop diversification were implemented in the most integrated manner, achieved 54\% higher grain energy yield with a $104 \%$ increase in economic returns, 35\% lower total water input, and a 43\% lower GWPi. Conservation agriculture practices were most suitable for intensifying as well as diversifying wheat-rice rotations, but less so for rice-rice systems. This finding also highlights the need for characterizing areas suitable for CA and subsequent technology targeting. A comprehensive baseline dataset generated in this study will allow the prediction of extending benefits to a larger scale.
\end{abstract}

Keywords: best management practices, cereal productivity, cereals systems, conservation agriculture, crop diversification, global warming potential, rice-based cropping system, South Asia

Received 19 August 2015; revised version received 15 October 2015 and accepted 23 October 2015

\section{Introduction}

South Asia has a total population of 1.6 billion, of which about 540 million people are poor and hungry and one-third are malnourished (FAO, 2012). It is esti-

Correspondence: Jagdish Kumar Ladha, tel. +91 116676 3000, fax+91 112584 1801, e-mail: j.k.ladha@irri.org mated that demand for food and nonfood commodities is likely to increase by at least $60 \%$ globally between 2010 and 2050, with many developing countries including those in South Asia having to double their food production (Tilman et al., 2011; Alexandratos \& Bruinsma, 2012). Future food production will be limited on a global scale by the availability of land, water, and energy therefore, decoupling future agricultural growth from 
the unsustainable use of these resources for increasing food production has become one of the cornerstones for a new sustainable development agenda (Dobermann et al., 2013; Rockström et al., 2013). As a cornerstone of the new sustainable development agenda, the agricultural transformation in the next few decades has to be an eco-efficient revolution, with at least $30-50 \%$ increases in the efficiency of scarce resources used while also ensuring the availability of nutritious food for all and minimizing many negative environmental impacts associated with contemporary food systems (Dobermann et al., 2013).

Agriculture in the Indo-Gangetic Plains (IGP) in South Asia is predominantly centered on the intensively irrigated rice-wheat systems with associated productivity and sustainability problems (Ladha et al., 2003). The problems, however, differ from the intensive systems in the northwest to those in the easternIGP, which are characterized by smaller farms, weaker institutions including markets and greater poverty. These differences reflect significant gradients in the resource base, crop management, and livelihoods across the IGP (Balasubramanian et al., 2012). During the last few years, several component technologies of conservation agriculture (CA) such as reduced or zero tillage, drill seeding, crop residue retention, and crop rotation have been evaluated in cereal systems (Ladha et al., 2003, 2009). Zero-till wheat has been adopted on a significant area in the rice-wheat system in the northwestern IGP (Harrington \& Hobbs, 2009) with positive impacts on wheat yield, profitability, and resource-use efficiency (Erenstein \& Laxmi, 2008; Ladha et al., 2009). Unlike wheat, rice continues to be almost entirely grown by the conventional practice of conventional wet tillage (puddling) and transplanting. Also, crop residues continue to be either burned or removed both in rice and wheat (Ladha et al., 2003). To harness the full potential of CA, more rice may also have to be brought under conservation tillage, but without negative impacts on yield and the overall systems performance. Surface residue retention provides multiple benefits, including soil moisture conservation, suppression of weeds, and improvement in soil organic matter and soil structure (Singh et al., 2007; Balwinder-Singh et al., 2011; Verhulst et al., 2011; Yadvinder-Singh et al., 2005). Recently, interest has been rapidly increasing in direct drill seeding or mechanical transplanting under nonpuddled/nonponded condition, due to increasing labor scarcity, energy constraints, and rising input costs (Kumar \& Ladha, 2011; Kumar et al., 2013). In future, in addition to shifting to CA-based improved practices, there is a need to explore other crops in the traditional cereal-based rotation. Crop rotations can have a positive influence on soil conditions, and the rotation of crops with different root architecture and physiology helps to access nutrients in different layers and chemical forms in the soil (Prochnow \& Cantarella, 2015).

Not all of the targets set by experts can be achieved at once and everywhere. Trade-offs will often be part of a general pathway towards achieving a sustainable intensification of agricultural production systems. Holistic management approaches and technology solutions will be required for the world's most important food production systems, particularly in the major grain-producing areas that must support future food and nutrition security. Hence, a multifaceted, tailored agro-ecological intensification of crop production must combine sound options for best agronomic management practices (BMPs) with modern genetic improvement (Dobermann et al., 2013). Quantitative measurement and participatory evaluation of future systems solutions are a core component of this, particularly with regard to CA solutions. Cropping systems that incorporate CA components may have substantial potential for spearheading another Green Revolution in South Asia (Gupta et al., 2003; Ladha et al., 2009). With more mechanized, labor-saving land management and crop establishment at center stage, the transformation from conventional tillage-based agriculture to conservation tillage with crop residue recycling is considered to be a crucial direction for transforming agriculture in South Asia and other regions (Hobbs et al., 2008). In addition, the integration of noncereal crops such as a legume in the system would strike a better nutritional balance and could improve soil and plant health and system productivity (Singh \& Ryan, 2015). However, achieving multiple economic and ecosystem benefits through CA remains a challenge in smallholder farming (Brouder \& Gomez-Macpherson, 2014; Palm et al., 2014), and its potential for climate change mitigation is also questionable (Powlson et al., 2014). A recent metaanalysis of global data reported either no gains or losses of grain yields of various crops with either full CA or with some components of CA (Pittelkow et al., 2014b). However, while yield advantages are not always possible to achieve with CA practices alone over the short term, gains in input use efficiency and economic benefits are attainable (Ladha et al., 2003, 2009; Kumar \& Ladha, 2011). Although the benefits of CA components are likely to be most when combined with other BMPs, this aspect largely remains unexplored. It is also uncertain to what extent future CA-based cereal systems in South Asia can be optimized to be more productive as well as meet many other requirements in terms of sustainable resource use and environmental impact.

Achieving an ambitious set of crop production targets to meet the ever-increasing demand for food due 
to the rapid population and income growth in Asia and at the same time making more efficient use of the available resources is not impossible, but current technologies and strategies are not adequate for this. To meet this challenge, promotion and adoption of cropping systems that integrated BMPs and CA components are essential from an agronomic view point. Hence, four cropping systems management scenarios (S1, S2, S3, and S4) were conceptualized with a vision to design and evaluate future trajectories for intensifying and diversifying cereal-based cropping systems that are highly productive, achieve optimal resourceuse efficiency, are economically viable, and are characterized by low global warming potential intensity (GWPi). This study provides new quantitative evidence from two years of data collected from four locations, that is, eight environments under the Cereal Systems Initiative for South Asia (CSISA). Four novel productionscale research platforms were established to represent a combination of distinctly different agro-ecological conditions and major food production systems of densely populated regions of South Asia. A suite of performance indicators related to grain energy and economic outputs, various inputs (water, labor, nitrogen, photosynthetically active solar radiation, and fossil fuel energy), and greenhouse gas (GHG) and global warming potential (GWP) were quantified (Table 4), and the data were subjected to mixed model analysis and biplot analysis.

\section{Materials and methods}

\section{Experimental sites}

This study used data collected during six seasons (dry, summer, and wet during 2009-2011) from four new research platforms established in 2009 in a regional program, the CSISA (http://csisa.org/). The experiments were conducted at four sites covering India and Bangladesh (Fig. 1): Western IGP: Karnal, Haryana, India; Central-IGP: Patna, Bihar, India; Eastern-IGP: Gazipur, Bangladesh; and Subtropical South India: Aduthurai, Tamil Nadu, India. The climate varied from semiarid, hot subhumid to subtropical, with annual rainfall ranging from 700 to $1800 \mathrm{~mm}$. The soils varied from loam, silty loam to clay, with total $\mathrm{C}$ ranging from 5.6 to $12.2 \mathrm{~g} \mathrm{~kg}^{-1}$ (Table 1). The test sites reflecting variation in climate, soil and biotic factors, cropping systems and farming practices were chosen to adequately represent the target region in South Asia.

\section{Research platforms in major agro-ecosystems of South Asia}

Trans (Western) IGP. This is one of South Asia's major cereal bowls. It includes parts of Pakistan (Punjab and Sindh) and India (Punjab, Haryana, and the western part of Uttar Pradesh). Intensive irrigated rice-wheat and cotton-wheat systems are most predominant, and focus is increasing on maize as an option to diversify the rice-wheat rotation. This is the Green Revolution heartland, with relatively low rural poverty. Its surplus production feeds urban centers and therefore

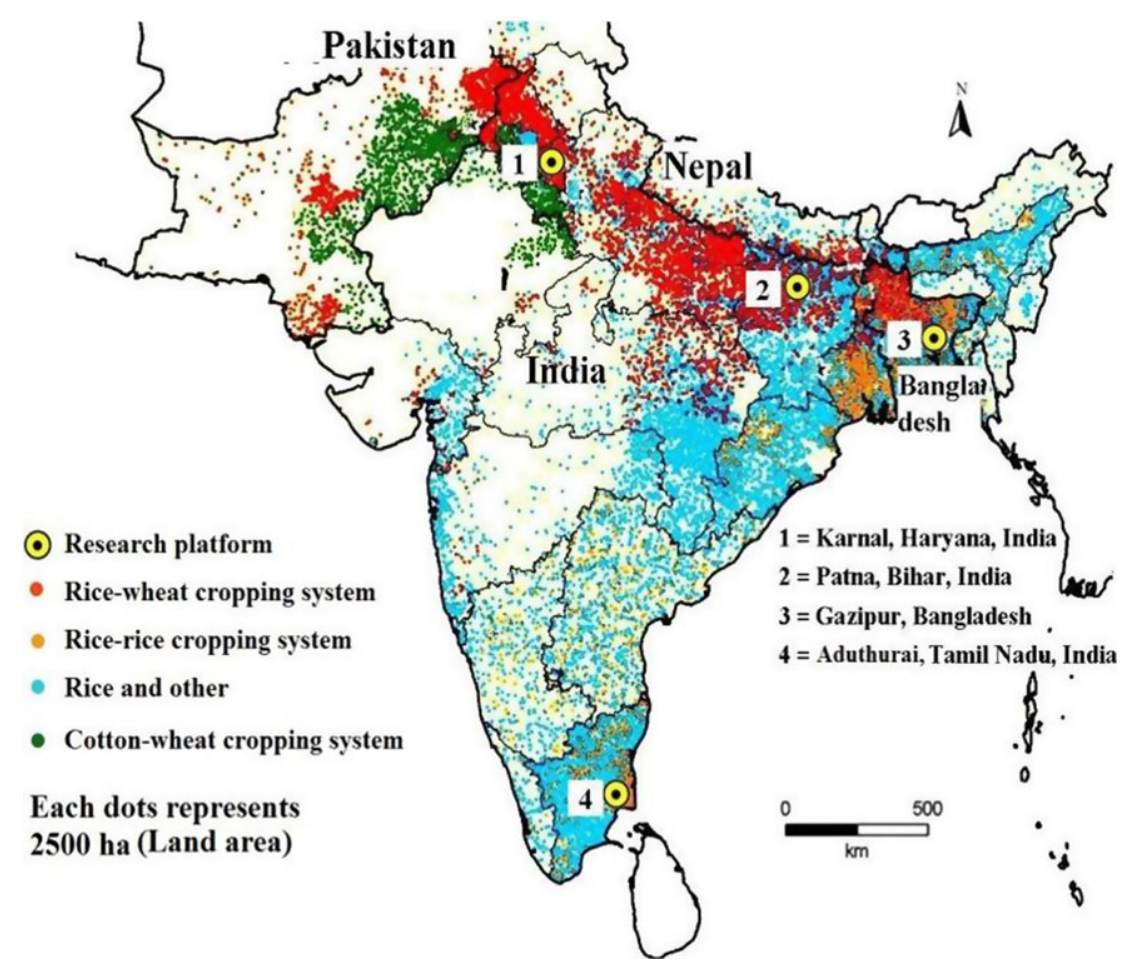

Fig. 1 A partial map of South Asia showing the four locations of the study with the major cropping systems in South Asia. 
Table 1 Initial site and soil (0-15 cm depth) characteristics of four research platforms in South Asia

\begin{tabular}{|c|c|c|c|c|}
\hline & $\begin{array}{l}\text { Karnal, Haryana, } \\
\text { India }\end{array}$ & Patna, Bihar, India & $\begin{array}{l}\text { Gazipur, } \\
\text { Bangladesh }\end{array}$ & $\begin{array}{l}\text { Aduthurai, Tamil } \\
\text { Nadu, India }\end{array}$ \\
\hline \multirow[t]{2}{*}{ Transact } & Trans-Gangetic Plains & Central Gangetic Plains & Lower Gangetic Plains & $\begin{array}{l}\text { Subtropical southern } \\
\text { part of India }\end{array}$ \\
\hline & Western & Central & Eastern & Southern \\
\hline Dominant crop rotation & Rice-wheat & Rice-wheat & Rice-rice & Rice-rice \\
\hline Climate & Semiarid & Subtropical humid & Hot subhumid & Subtropical \\
\hline Latitude/altitude & $29^{\circ} 70^{\prime} \mathrm{N}, 76^{\circ} 96^{\prime} \mathrm{E}$ & $25^{\circ} 24.912^{\prime} \mathrm{N}, 85^{\circ} 03.536^{\prime} \mathrm{E}$ & $23^{\circ} 59^{\prime} \mathrm{N}$ and $90^{\circ} 24^{\prime} 08^{\prime \prime} \mathrm{E}$ & $11^{\circ} 0.007 \mathrm{~N} / 79^{\circ} 48^{\prime \prime} \mathrm{E}$ \\
\hline Annual rainfall (mm) & 700 & 1130 & 1550 & 1142 \\
\hline Minimum temperature $\left({ }^{\circ} \mathrm{C}\right)$ & $0-4$ & $7-9$ & $10-13$ & $24-26$ \\
\hline Maximum temperature $\left({ }^{\circ} \mathrm{C}\right)$ & $41-44$ & $36-41$ & $33-35$ & $33-39$ \\
\hline Clay $\left(\mathrm{g} \mathrm{kg}^{-1}\right)$ & 199 & 439 & 283 & 465 \\
\hline Silt $\left(\mathrm{g} \mathrm{kg}^{-1}\right)$ & 461 & 418 & 539 & 228 \\
\hline Sand $\left(\mathrm{g} \mathrm{kg}^{-1}\right)$ & 340 & 143 & 181 & 308 \\
\hline Soil texture & Loam & Silty clay & Silty clay loam & Clay \\
\hline $\mathrm{pH}(1: 1$ soil : water $)$ & $8.00 \pm 0.02$ & $7.50 \pm 0.00$ & $4.83 \pm 0.30$ & $7.46 \pm 0.02$ \\
\hline $\mathrm{EC}\left(\mathrm{dS} \mathrm{m}^{-1}\right)(1: 1$ soil : water $)$ & $0.37 \pm 0.02$ & $0.33 \pm 0.00$ & $0.54 \pm 0.50$ & $0.50 \pm 0.03$ \\
\hline Total $\mathrm{C}\left(\mathrm{g} \mathrm{kg}^{-1}\right)$ & $5.6 \pm 0.1$ & $8.0 \pm 0.1$ & $11.0 \pm 0.2$ & $12.2 \pm 0.2$ \\
\hline Total $\mathrm{N}\left(\mathrm{g} \mathrm{kg}^{-1}\right)$ & $0.6 \pm 0.02$ & $0.9 \pm 0.1$ & $0.9 \pm 0.2$ & $1.0 \pm 0.02$ \\
\hline Exchangeable $\mathrm{K}\left(\mathrm{mg} \mathrm{kg}^{-1}\right)$ & $130 \pm 1.7$ & $167 \pm 4.0$ & $80 \pm 41.3$ & $194 \pm 10.2$ \\
\hline Available (Olsen) P (mg kg-1) & $5.74 \pm 0.3$ & $12.90 \pm 0.5$ & $8.66 \pm 0.6$ & $11.07 \pm 0.7$ \\
\hline Particle density $\left(\mathrm{g} \mathrm{cm}^{-3}\right)$ & $2.57 \pm 0.01$ & $2.50 \pm 0.00$ & $2.48 \pm 0.10$ & $2.43 \pm 0.00$ \\
\hline
\end{tabular}

is important to overall food security. Its future productivity is threatened, however, by resource scarcity and degradation, especially the increasing shortages of agricultural labor and water and, in some locations, deterioration in water quality. This region has excellent potential to diversify into highervalue products where CA-based practices can enable a greater diversification and overall higher system efficiency.

Central Gangetic Plains. This terrain includes the Nepal Terai and the northeastern parts of India (Uttar Pradesh and Bihar) and is densely populated, with rampant rural poverty. Institutional support, infrastructure, and markets are typically poorly developed. Here, the Green Revolution made some contributions but less than in the Western IGP. Rice-wheat systems predominate but are less intensive and productive than in the Western IGP. This region with relatively ample groundwater has much potential for intensification and therefore is envisioned to make major contributions to future cereal supply.

Lower (Eastern) Gangetic Plains. This region spans Bangladesh and the Indian state of West Bengal and is home to the world's highest rural population. Cropping patterns are largely rice based, with varying cropping systems found along the topo-sequence. Because of its high yield potential, cool-season 'boro' rice has become important in areas with adequate irrigation. Elsewhere, especially in the north, winter crops such as maize and wheat are grown. The potential to intensify cropping toward diversified triple-cropping systems is remarkable, and the application of appropriate CA-based practices that reduce crop turnaround time will be crucial.
Subtropical southern part of India. This region with subtropical climate has a limited role for wheat, but the Green Revolution transformed irrigated areas into an intensive double-cropped rice-rice system. The future contribution of these systems is threatened by productivity stagnation, water scarcity, and resource degradation. In addition to introducing improved rice management practices, potential exists for alternate crops such as maize and additional crops such as legumes.

Despite regional differences and different priorities, all four agro-ecosystems have the following in common: (i) the need to better exploit existing yield potential, including adapting to a changing climate; (ii) the need for mechanization of most cropping practices in response to rising labor costs and labor shortages; (iii) opportunities for diversification of cropping systems for better nutrition and higher income; and (iv) pressing needs for improving soil quality and water and nitrogen use efficiency.

\section{Experimental details}

Two broad groups of cereal-based rotations were considered: wheat-rice and rice-rice with integration of either a legume or substituting wheat or rice with maize and/or potato (Table 2). Crop production was distributed across the three seasons that occur in this region: the cool, dry winter season (rabi or boro; November to March), the hot, dry summer season (April to May), and the wet/rainy season (kharif or aman; June to November) at all sites except Aduthurai where rabi is also a wet season.

Prior to the start of the experiment, a crop of rice (cover crop) was grown across the sites to promote site uniformity. 
Table 2 Environments (site $\times$ year) and scenario-wise cropping systems used

\begin{tabular}{|c|c|c|c|c|c|c|}
\hline Site & Year & $\begin{array}{l}\text { Environment } \\
\text { no. }\end{array}$ & Scenario 1 & Scenario 2 & Scenario 3 & Scenario 4 \\
\hline \multirow[t]{2}{*}{ Karnal } & 1 & K1 & \multirow[t]{2}{*}{ Wheat-fallow-rice } & \multirow[t]{2}{*}{ Wheat-mungbean-rice } & \multirow[t]{2}{*}{ Wheat-mungbean-rice } & \multirow{2}{*}{$\begin{array}{l}\text { Wheat-mungbean- } \\
\text { maize }\end{array}$} \\
\hline & 2 & K2 & & & & \\
\hline \multirow[t]{2}{*}{ Patna } & 1 & $\mathrm{P} 1$ & \multirow[t]{2}{*}{ Wheat-fallow-rice } & \multirow[t]{2}{*}{ Wheat-mungbean-rice } & \multirow[t]{2}{*}{ Wheat-cowpea-rice } & \multirow{2}{*}{$\begin{array}{l}\text { Potato }+ \text { maize } \\
\text { (intercropped)-cowpea- } \\
\text { rice }\end{array}$} \\
\hline & 2 & $\mathrm{P} 2$ & & & & \\
\hline \multirow[t]{2}{*}{ Gazipur } & 1 & G1 & \multirow[t]{2}{*}{ Rice-fallow-rice } & \multirow[t]{2}{*}{ Rice-lablabbean-rice } & \multirow[t]{2}{*}{ Rice-lablabbean-rice } & \multirow[t]{2}{*}{ Potato-maize-rice } \\
\hline & 2 & G2 & & & & \\
\hline \multirow[t]{2}{*}{ Aduthurai } & 1 & A1 & \multirow[t]{2}{*}{ Rice-fallow-rice } & \multirow[t]{2}{*}{ Rice-blackgram-rice } & \multirow[t]{2}{*}{ Rice-blackgram-rice } & \multirow[t]{2}{*}{ Rice-maize-maize } \\
\hline & 2 & A2 & & & & \\
\hline
\end{tabular}

K1, Karnal year 1; K2, Karnal year 2; P1, Patna year 1; P2, Patna year 2; G1, Gazipur year 1; G2, Gazipur year 2; A1, Aduthurai year $1 ;$ A2, Aduthurai year 2.

After the harvest of the cover crop, the entire experimental area was leveled (zero gradient) using a laser-equipped drag scraper (Trimble ${ }^{\mathrm{TM}}$, Sunnyvale, CA, USA) with an automatic hydraulic system powered by a $60-\mathrm{HP}$ tractor. The details of all the field operations and crop management, including land preparation, tillage, variety, crop establishment (seed treatment, seeding or transplanting, seed rate, sowing or transplanting time), fertilizer management, water management, and pest management for all the crops under each scenario can be found elsewhere (Gathala et al., 2013; Laik et al., 2014; Alam et al., 2015).

\section{Scenarios}

The four scenarios (S1-S4) were designed in response to the following key challenges: growing demand for nutritious food, the impacts of climate change, increasingly limited resource base, rising labor and energy costs, and the environmental footprint of intensive agriculture (Table 3). Each scenario had a specific objective of either maintaining or improving current productivity, economic returns, nutritional value, and input use efficiency together with building the resource base. Each scenario was replicated thrice in production-scale plots, each of 0.2 ha size, in a randomized complete block design. The four scenarios had two broad groups of annual cereal-based rotations: wheat-rice or ricerice (S1-S4) with integration of a legume (S2-S4) and substitution of wheat or rice with maize and/or potato (S4) (Table 2). Scenario 1 was business as usual - farmers' conventional management practices, including intensive tillage and residue removal. Scenarios $2-4$ had a package of recommended best management practices (BMPs) comprising modern mechanization and tested agronomic interventions or existing expert knowledge chosen to match the requirements of the different crops. In addition, varying components of CA practices were included in different crops in a cropping system: conservation tillage and soil residue cover only in dry-season crops (S2), all crops (S3), and a majority of crops (S4). The rationale for varying CA components in S2-S4 was that farmers have rarely adopted full CA in their cropping system portfolio (Ladha et al., 2009). Often farmers adopted CA in dry season or upland crops in lowland-upland (i.e., rice-wheat system) ecology because the dry season is the one predicted to have the largest impact. Therefore, we designed S2 as CA in only the dry-season crops. At the other end of the spectrum, CA was included in all crops of S3 (conventional rice and wheat-based rotation with legume) and S4 (intensive crop diversification except potato in Patna and Gazipur which could not be planted in no-till, and residue mulched because of excess soil moisture).

In $\mathrm{S} 1$, crop varieties used were those adopted by most farmers in the region, whereas in S2-S4, crop varieties were improved varieties released more recently. Varieties were chosen to fit in each cropping system based on crop duration and adaptation to the local climate. This explains why varieties sometimes differed among scenarios in a given location. Farmers' conventional management practices in S1 and BMPs and CA in S2-S4 are described below.

\section{Farmers' common practices (Scenario 1)}

Farmers' crop rotation and management practices were adopted based on village surveys around each of the four sites. Forty to 260 farmers at each site were surveyed prior to the study to make an inventory of their common practices. Most farmers surveyed either burned or removed the crop residue for animal feed. However, in our study, we removed residue in S1. Upland crops were grown by broadcasting in intensively tilled (3-6 tillages) soils. Rice was grown by random transplanting (two to six 40- to 45-day-old seedlings for boro/dry-season rice and 28- to 35-day-old seedlings for wetseason rice) manually in puddled (wet tillage) soils. Farmers used crop cultivars/inbreds that were most popular in their respective regions. Weed management included a combination of hand weeding and herbicide. Insect and disease control were carried out by adopting the most common practices followed by farmers. Flood irrigation was the most common water management in upland crops, and rice was kept from near saturation to continuously flooded during most parts of 
Table 3 Scenario attributes

\begin{tabular}{|c|c|c|c|c|}
\hline & Scenario 1 & Scenario 2 & Scenario 3 & Scenario 4 \\
\hline Drivers of change & Business-as-usual & $\begin{array}{l}\text { Rising cost of } \\
\text { cultivation, input } \\
\text { use inefficiencies }\end{array}$ & $\begin{array}{l}\text { Rising cost of } \\
\text { cultivation, input } \\
\text { use inefficiencies, } \\
\text { shortages of labor } \\
\text { and water }\end{array}$ & $\begin{array}{l}\text { Diversification, input } \\
\text { use inefficiencies, } \\
\text { limited resources, } \\
\text { socioeconomic, } \\
\text { environmental } \\
\text { protection }\end{array}$ \\
\hline Goal & $\begin{array}{l}\text { Maintain current } \\
\text { system productivity } \\
\text { and input use efficiency }\end{array}$ & $\begin{array}{l}\text { Optimize system } \\
\text { productivity, income, } \\
\text { and input use efficiency }\end{array}$ & $\begin{array}{l}\text { Optimize system } \\
\text { productivity, income, } \\
\text { and input (especially } \\
\text { labor and water) use } \\
\text { efficiency and improve } \\
\text { soil health }\end{array}$ & $\begin{array}{l}\text { Maximize system } \\
\text { productivity, input } \\
\text { use efficiency and } \\
\text { income, and crop } \\
\text { rotation with crop } \\
\text { diversification and } \\
\text { reduce greenhouse } \\
\text { gas emissions }\end{array}$ \\
\hline $\begin{array}{l}\text { Crop rotation and } \\
\text { multiple cropping } \\
\text { intensity (MCI \%) }\end{array}$ & $\begin{array}{l}\text { Cereal based and } \\
200 \mathrm{MCI}\end{array}$ & $\begin{array}{l}\text { Cereal based with } \\
\text { legume and } 275 \mathrm{MCI}\end{array}$ & $\begin{array}{l}\text { Cereal based with } \\
\text { legume and } 275 \mathrm{MCI}\end{array}$ & $\begin{array}{l}\text { Cereal based with } \\
\text { vegetable or legume } \\
\text { and } 310 \mathrm{MCI}\end{array}$ \\
\hline Management & $\begin{array}{l}\text { Farmers' practices with } \\
\text { conventional tillage, } \\
\text { crop residue removed } \\
\text { and farmers' crops rotation }\end{array}$ & $\begin{array}{l}\text { Best management } \\
\text { (land, water, fertilizer, } \\
\text { and crop) practices } \\
\text { (BMP) with conservation } \\
\text { agriculture (CA) } \\
\text { practices in only dry } \\
\text { season crop in the rotation }\end{array}$ & $\begin{array}{l}\text { BMP with CA practices } \\
\text { in all crops in the rotation }\end{array}$ & $\begin{array}{l}\text { BMP with CA } \\
\text { practices in all the } \\
\text { diversified crops } \\
\text { except potato in the } \\
\text { rotation }\end{array}$ \\
\hline
\end{tabular}

the growing season. Fertilizer use was frequently unbalanced and suboptimal in terms of both rate and timing.

\section{Best management and CA practices (Scenarios 2-4)}

Wheat. (i) Sowing, recommended improved variety, in a notill system by using new-generation planters at optimum spacing (20 cm $\times$ continuous) in rice crop residue; (ii) weed control by presowing and postemergence application of herbicides; (iii) irrigation water was applied 4-6 times at the critical stages (crown root initiation, tillering, jointing, flowering, milk, and grain filling) and each irrigation was measured at $5 \mathrm{~cm}$ height standing water; (iv) applying the adequate recommended nutrients following improved local recommendations or site-specific nutrient management (SSNM) principles to achieve attainable yields (Khurana et al., 2008).

Rice. Transplanted: (i) improved raised bed or mat nursery to produce robust, healthy young rice seedlings of recommended improved variety; (ii) applying nutrients in the nursery to provide rice seedlings with adequate nutrition and to minimize transplanting shock; (iii) optimum seedling age (37-39 days in dry-season rice (boro), 22-30 days for manually transplanted wet-season rice, and 16-18 days for machine-transplanted rice); (iv) planting 1-2 seedlings per hill at $20 \times 15 \mathrm{~cm}$ or $20 \times 20 \mathrm{~cm}$ spacing either in puddled (conventional-till) or unpuddled (reduced-till) condition; (v) water management included flooding or wetting for the first 20-25 days after transplanting, followed by irrigation with alternate wetting and drying (AWD); (vi) weed management by pre-emergence herbicide application followed by one hand weeding; (vii) applying adequate nutrients at the right time and following local recommendations or SSNM principles to ensure high yields (Dobermann et al., 2004).

Rice. Dry direct seeding: (i) dry direct-seeded rice (zero-till/ reduced-till) was sown at optimum spacing $(20 \mathrm{~cm} \times$ continuous) with $20-25 \mathrm{~kg} \mathrm{ha}^{-1}$ seed of recommended improved variety; (ii) kept soil wet for first 20 days for good crop establishment and then irrigation water was applied using tensiometers ( -20 to $-30 \mathrm{kPa}$ at $15-\mathrm{cm}$ depth); (iii) weed control by pre- and postemergence herbicides followed by need-based spot hand weeding; and (iv) applying adequate nutrients at the right time and following local recommendations SSNM principles to ensure high yields (Dobermann et al., 2004).

Maize. (i) Optimum planting density $(60 \times 20 \mathrm{~cm}$ spacing); (ii) planted by manual dibbling of seeds if recommended improved variety in conventional-till, and by new-generation planters in a no-till or reduced-till system; (iii) earthing-up at seedling stage in a conventional system (which makes furrows in between rows and also serves the purpose of weeding), and mulching with crop residue in a zero-till or reduced-till system; (iv) weed control with preplant herbicide application followed by need-based one hand weeding; (v) irrigation water applied 0-4 times depending on season and rainfall pattern, and each time water applied up to the time when water reaches $5 \mathrm{~cm}$ water height; (vi) nutrient management as per 
the latest research recommendations following SSNM (Pasuquin et al., 2014).

Potato. (i) Optimum planting density $(60 \times 25 \mathrm{~cm}$ spacing $)$; (ii) need-based earthing-up at germination/emergence and at 15-20 days after germination, which makes furrows in between rows and also serves the purpose of weeding; (iii) irrigation water applied 2-3 times by furrow irrigation method and each time water applied up to the time when two-thirds of the furrows from the bottom are filled with water; and (iv) applying adequate nutrients at the right time following the recommendations made by national research systems. Potato was planted in S4 in Patna and Gazipur with reduced tillage, and its residue was partly amended in soil.

Legumes. (i) Sowing at optimum spacing (20-30 cm $\times$ continuous) in no-till or reduced-till in lines either manually or using a drill; (ii) need-based one-time hand weeding; (iii) where a legume was grown after wheat, 1-2 irrigation water applications and basal $\mathrm{P}$ and $\mathrm{K}$ fertilization; and (iv) where a legume was grown after potato, no irrigation or fertilization.

\section{Measurements/data collection}

Crop and soil measurements, including sampling, processing, and analyses, were made using standard experimental protocols. Data with a wide range of parameters were used to assess system performance (Table 4). The following broad groups of parameters were considered as follows: outputs (productivity, economic returns), inputs (water, photosynthetically active solar radiation, fertilizer N, labor, energy), and GWP. Details of various measurements and calculations of efficiencies are provided elsewhere (Gathala et al., 2013; Laik et al., 2014; Alam et al., 2015) except for the accounting of energy and quantification of GHG $\left(\mathrm{CH}_{4}\right.$ and $\left.\mathrm{N}_{2} \mathrm{O}\right)$ emissions and GWP, which are provided below. Using the primary parameters (outputs and inputs), various efficiency parameters (secondary) were calculated (Table 4). Instead of grain yield or grain yield rice equivalent (GY or GYRE), the equivalent grain energy yields (GEY) of all the crops were used to calculate all the efficiency parameters. This was made to eliminate confounding effects of (i) large inherent differences in the amounts of biomass of economic output and (ii) the fluctuating market price of the economic output of the diverse crops

Table 4 Performance indicators evaluated in all scenarios

\begin{tabular}{|c|c|c|c|c|}
\hline S. no. & Parameter & Abbreviation & Unit & Source \\
\hline 1. & Multiple cropping index & MCI & $\%$ & $\begin{array}{l}\text { Calculated (sum of area of crops grown } \\
\text { in } 365 \text { days } / \text { ha } \times 100 \text { ) }\end{array}$ \\
\hline 2. & Grain yield & GY & $\mathrm{Mg} \mathrm{ha}^{-1}$ & Measured \\
\hline 3. & Grain yield rice equivalent & GYRE & $\mathrm{Mg} \mathrm{ha}^{-1}$ & $\begin{array}{l}\text { Calculated [nonrice crop yield } \\
\left(\mathrm{Mg} \mathrm{ha}^{-1}\right) \times \text { farm gate price of } \\
\text { nonrice crop }\left(\mathrm{US} \$ \mathrm{mg}^{-1}\right) / \text { farm gate } \\
\left.\text { price of rice }\left(\mathrm{US} \$ \mathrm{mg}^{-1}\right)\right]\end{array}$ \\
\hline 4. & Grain energy yield & GEY & GJ ha ${ }^{-1}$ & $\begin{array}{l}\text { Calculated (GY × grain energy } \\
\text { conversion factor: see Methods) }\end{array}$ \\
\hline 5. & Irrigation water input & IWI & $\mathrm{mm} \mathrm{ha}^{-1}$ & Measured \\
\hline 6. & Irrigation water productivity & IWP & GJ $\mathrm{m}^{3}$ & Calculated (GEY/IWI) \\
\hline 7. & Total (irrigation + rain) water input & TWI & $\mathrm{mm} \mathrm{ha}^{-1}$ & Measured \\
\hline 8. & $\begin{array}{l}\text { Total (irrigation }+ \text { rain) water } \\
\text { productivity }\end{array}$ & TWP & GJ $\mathrm{m}^{3}$ & Calculated (GEY/TWI) \\
\hline 9. & $\begin{array}{l}\text { Photosynthetically active radiation } \\
\text { incident (from sowing to maturity) }\end{array}$ & PARi & GJ ha ${ }^{-1}$ & Measured \\
\hline 10. & $\begin{array}{l}\text { Photosynthetically active radiation } \\
\text { conversion efficiency }\end{array}$ & PARCE & GJ GJ ${ }^{-1} \times 100$ & Calculated (GEY/PARi) \\
\hline 11. & Nitrogen fertilizer input & NI & $\mathrm{kg} \mathrm{ha}^{-1}$ & Measured \\
\hline 12. & Partial factor productivity of $\mathrm{N}$ & PFP-N & GJ $\mathrm{kg} \mathrm{N}^{-1}$ & Calculated (GEY/NI) \\
\hline 13. & Residue input & RI & $\mathrm{Mg} \mathrm{ha}^{-1}$ & Measured \\
\hline 14. & Labor input & LI & Person-days ha ${ }^{-1}$ & Measured \\
\hline 15. & Labor productivity & LP & GJ day ${ }^{-1}$ & Calculated (GEY/LI) \\
\hline 16. & Energy input & EI & GJ ha ${ }^{-1}$ & Measured and calculated (see Methods) \\
\hline 17. & Net energy ratio & NER & GJ GJ ${ }^{-1}$ & Calculated (GEY/EI) \\
\hline 18. & Cost & COST & US\$ ha ${ }^{-1}$ & Measured \\
\hline 19. & Grain energy expenditure & GEE & US\$ $\mathrm{GJ}^{-1}$ & Calculated (COST/GEY) \\
\hline 20. & Net income & NIC & US\$ ha ${ }^{-1}$ & $\begin{array}{l}\text { Calculated [gross returns (US\$ ha }{ }^{-1} \text { ) } \\
\text { total variable cost }\left(\text { US } \$ \mathrm{ha}^{-1}\right) \text { ] }\end{array}$ \\
\hline 21. & Grain energy profit & GEP & US\$ $\mathrm{GJ}^{-1}$ & Calculated (NIC/GEY) \\
\hline 22. & Global warming potential & GWP & $\mathrm{kg} \mathrm{CO}_{2}$ eq ha ${ }^{-1}$ & Measured and modeled \\
\hline 23. & Global warming potential intensity & GWPi & $\mathrm{kg} \mathrm{CO}_{2}$ eq $\mathrm{MJ}^{-1}$ & Calculated (GWP/GEY) \\
\hline
\end{tabular}


used in the estimations of GYRE. The GEY in GJ ha ${ }^{-1}$ is the energy attained from the crop in harvested yield and was calculated by multiplying the GY achieved in the field by crop grain energy conversion (on a dry weight basis for all the crops except potato, which is on a fresh weight basis) factor (rice and wheat $=14.5 \mathrm{MJ} \mathrm{kg}^{-1} ; \quad$ maize $=14.31 \mathrm{MJ} \mathrm{kg}^{-1}$; potato $=4.06 \mathrm{MJ} \mathrm{kg}^{-1}$; mungbean, blackgram and cowpea $=14 \mathrm{MJ} \mathrm{kg}^{-1}$ (Gopalan et al., 1978).

\section{Account of energy inputs}

The energy equivalent (MJ unit ${ }^{-1}$ ) of each input was used for calculating total energy input in each scenario. Fuel consumption was recorded during each field operation (tillage, seeding, intercultural operations, and harvesting) to calculate energy consumption. Energy usage during irrigation was calculated from the electricity and/or diesel consumed during each irrigation. The use of other inputs, for example, seed, fertilizer, chemicals, human labor, was recorded, and energy input was calculated for each operation, including sowing/transplanting, bund/channel making, irrigation, spraying of herbicides, weeding, top-dressing of fertilizer, harvesting, threshing, and transportation, using the energy equivalents tabulated by (Kumar et al., 2013) (adapted from Shahin et al., 2008).

\section{Measurement of GHG emissions and calculations of GWP}

Greenhouse gas $\left(\mathrm{CH}_{4}\right.$ and $\left.\mathrm{N}_{2} \mathrm{O}\right)$ fluxes were measured in the two main crops in the dry and wet seasons at two sites [using gas chromatography (GC) and photo-acoustic infrared gas monitoring system (PAS) at Karnal and using GC at Aduthurai] following the protocols of Tirol-Padre et al. (2014). Gas samples were collected between 09:00 and 13:00 h every day for 5 days after every fertilizer $\mathrm{N}$ application and weekly in between fertilizer applications. For GC, gas samples were collected four times within the total chamber deployment time of $30 \mathrm{~min}$ at $10-\mathrm{min}$ intervals. For PAS measurements, $50-\mathrm{m}$ plastic tubing of $3 \mathrm{~mm}$ diameter was connected to the inlet and outlet ports of the gas chamber and the PAS. The GC and PAS measurements were taken from the same location (same base per plot) on the same day (Tirol-Padre et al., 2014). Chamber deployment time for GC sampling was $30 \mathrm{~min}$, while that for PAS was only $12 \mathrm{~min}$. The daily $\mathrm{CH}_{4}$ and $\mathrm{N}_{2} \mathrm{O}$ emission rates were calculated from the linear increase (slope) in GHG concentration over time. Seasonal emissions were estimated from the sum of daily emission rates. Daily emissions in between weekly measurements were estimated from linear interpolation of two consecutive weekly measurements. As the fluxes measured by GC and PAS had good agreement, averages were used.

The DeNitrification and DeComposition (DNDC) model version 9.3 (Li et al., 1992a,b, 1994; ISEOS, 2009) was calibrated against observed $\mathrm{CH}_{4}$ and $\mathrm{N}_{2} \mathrm{O}$ emissions in the rice-wheat and rice-rice systems under different water, field, and soil management in Karnal and Aduthurai. Actual values of soil properties (SOC, clay contents, $\mathrm{pH}$, and bulk density), daily meteorological data (maximum and minimum temperatures and precipitation), thermal degree days, water use efficiency ( $\mathrm{g}$ water $\mathrm{g}^{-1}$ dry matter), amount of residues, flooding and drainage dates for rice, and irrigation dates for wheat and maize were used as inputs for DNDC. The leaking rate in Karnal was adjusted based on the observed water infiltration rate in the experimental field. In Karnal, the $\mathrm{CH}_{4}$ emissions under four $\mathrm{N}$ rates during two rice cropping seasons were simulated using DNDC. Intermittent flooding was applied during both seasons but floodwater levels and drainage events varied between the two seasons. The changes in the flooding and drainage events (frequency and timing/dates relative to $\mathrm{N}$ application) resulted in substantial changes in $\mathrm{CH}_{4}$ and $\mathrm{N}_{2} \mathrm{O}$ fluxes simulated by DNDC, which correlated with actual measured values. In Aduthurai, the $\mathrm{CH}_{4}$ emissions at four $\mathrm{N}$ rates were simulated under continuous flooding using DNDC. The measured $\mathrm{CH}_{4}$ emissions were not significantly different from the DNDC-simulated values. In wheat, significant changes in DNDC-simulated $\mathrm{N}_{2} \mathrm{O}$ fluxes expressed in $\mathrm{kg} \mathrm{ha}^{-1}$ were obtained with changes in $\mathrm{N}$ fertilizer rates. High correlations were also obtained between observed and simulated values. After validation of the DNDC model using $\mathrm{CH}_{4}$ and $\mathrm{N}_{2} \mathrm{O}$ emission data from Karnal and Aduthurai, the $\mathrm{CH}_{4}$ and $\mathrm{N}_{2} \mathrm{O}$ emissions were simulated for Patna and Gazipur, where no actual gas measurements could be made. However, actual meteorological, soil, and water data collected from Patna and Gazipur were used as model inputs for simulating $\mathrm{CH}_{4}$ and $\mathrm{N}_{2} \mathrm{O}$ emissions by DNDC. Total dry matter, grain yield, and $\mathrm{N}$ uptake were also measured at maturity at all sites and compared with simulated values. Some adjustments were made on the maximum grain biomass and biomass fractions in grain, leaf + stem, and roots used as model inputs to obtain closer fit between observed and simulated $\mathrm{C}$ and $\mathrm{N}$ yields.

The average GWP from $\mathrm{CH}_{4}$ plus $\mathrm{N}_{2} \mathrm{O}$ emissions from four sites were relatively higher than the average GWP from $\mathrm{CH}_{4}$ plus $\mathrm{N}_{2} \mathrm{O}$ emissions from Karnal and Aduthurai (where actual GHG measurements were made). However, the trends across the four scenarios were similar in both cases including lower GWP in S4 (Fig. 2). This suggests that the results will not change if the data simulated based on the DNDC model were included as compared to using only the actual measurements of GHG fluxes.

The $\mathrm{CH}_{4}$ and $\mathrm{N}_{2} \mathrm{O}$ emission factors were converted to gross GWP using the GWP factors (25 for $\mathrm{CH}_{4}$ and 298 for $\mathrm{N}_{2} \mathrm{O}$ ) relative to $\mathrm{CO}_{2}$ over a 100-year time horizon. The GWP associated with fertilizer, herbicide, and pesticide manufacture, and electricity and diesel use was calculated based on emission factors from published literature (Table 5).

\section{Statistical analysis}

The cropping intensity, crop rotations, and management practices (BMP and CA) across locations for a given scenario were identical except for the crops in rotation in S4 (Tables 2 and 3). In S4, where crop diversification required crop substitution, other crops were grown in the rotation. However, the responses of diverse crops to management practices are 


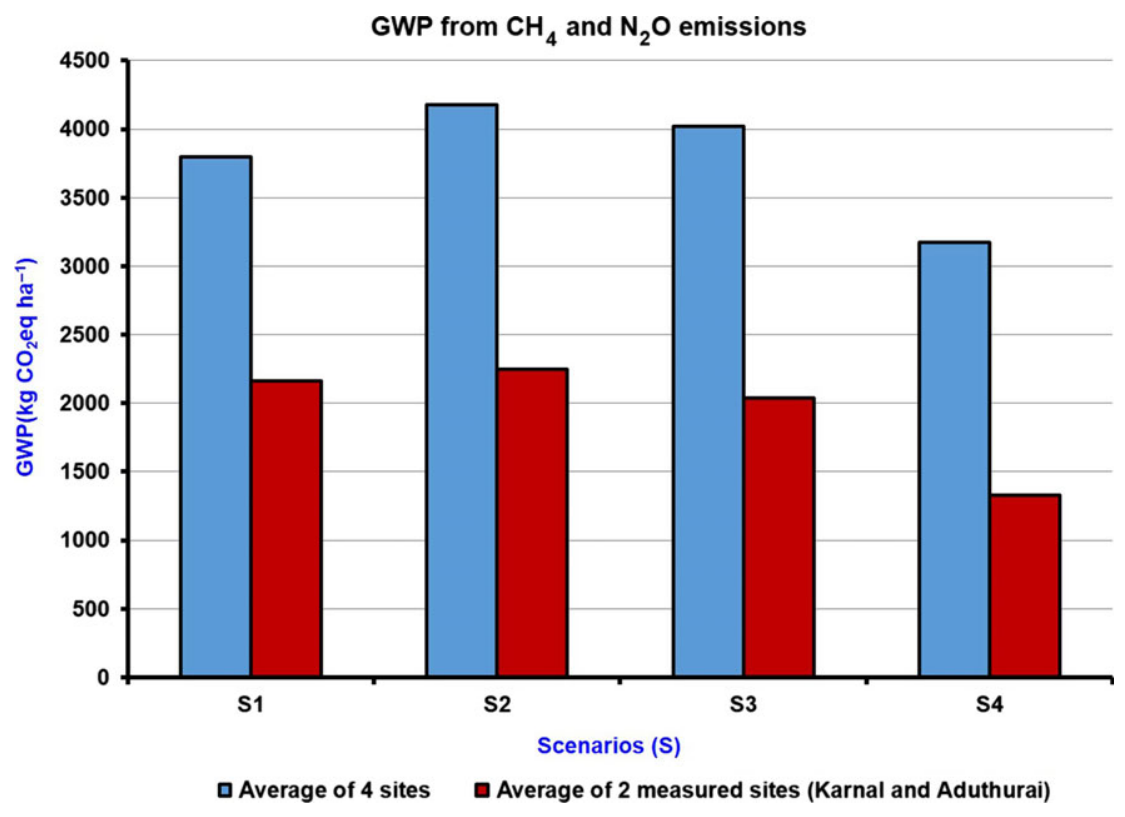

Fig. 2 Comparison of average global warming potential (GWP) (from $\mathrm{CH}_{4}$ and $\mathrm{N}_{2} \mathrm{O}$ emissions) from four sites with that of GWP (from $\mathrm{CH}_{4}$ and $\mathrm{N}_{2} \mathrm{O}$ emissions) measured at two sites (Karnal and Aduthurai).

Table 5 GHG emission factors of agricultural inputs

\begin{tabular}{lll}
\hline Input & $\begin{array}{c}\text { Emission factor } \\
(\mathrm{kg} \mathrm{CO} \text { eq. per } \\
\text { unit of input })\end{array}$ & Source \\
\hline Diesel fuel & $2.68 \mathrm{~L}^{-1}$ & $\begin{array}{c}\text { USEIA Energy Information } \\
\text { Administration (2011) }\end{array}$ \\
Electricity & $0.994 \mathrm{kw} \mathrm{h}^{-1}$ & CFT (2014) \\
Urea $46 \%$ & $2.55 \mathrm{~kg}^{-1}$ product \\
Superphosphate $21 \%$ & $0.57 \mathrm{~kg}^{-1}$ product & \\
Muriate of potash $60 \%$ & $0.32 \mathrm{~kg}^{-1}$ product & \\
Diammonium phosphate & $1.27 \mathrm{~kg}^{-1}$ product & \\
(18\% $\mathrm{N}$, 46\% $\left.\mathrm{P}_{2} \mathrm{O}_{5}\right)$ & $26.63 \mathrm{~kg}^{-1}$ a.i. & Audsley et al. (2009) \\
Average pesticide & $24.20 \mathrm{~kg}^{-1}$ a.i. & Grassini \& Cassman (2012) \\
Average herbicide & &
\end{tabular}

expected to be similar across locations. Therefore, the four scenarios across locations were treated as the same. As the analysis involved multiple crops in four scenarios, the grain yield data of each crop were converted into energy, which was used to calculate all the efficiency parameters. The converted data were then aggregated across seasons for each parameter. Scenario means were estimated for each environment (site $\times$ years cross classification, Table 6) based on the annual-cropping system aggregate data with respect to parameters based on both per unit land area $\left(\mathrm{ha}^{-1}\right)$ and per unit food energy $\left(\mathrm{GJ}^{-1}\right)$ produced. The environment-wise analysis was carried out using the MIXED procedure of SAS (Littell et al., 2006) taking scenarios as fixed and replicates within environments as random. The data consisting of eight environments in all were then subjected to a combined analy- sis of variance over environments using a model in which scenario effects were considered fixed and environmental effects were set to random to predict treatment performances for future years in the target region. The observations of the $i$ th scenario in the $k$ th replicate within the $j$ th environment with respect to any parameter are modeled as

$$
y_{i j k}=\mu+s_{i}+e_{j}+r_{k j}+(s e)_{i j}+\varepsilon_{i j k}
$$

where $\mu$ is the overall mean, $s_{i}$ is the scenario main effect, $e_{j}$ is the environmental main effect, $r_{k j}$ is the effect of the $k$ th replicate within the $j$ th environment, $(s e)_{i j}$ is the interaction between scenario $i$ and environment $j$, and $\varepsilon_{i j k}$ is the plot error. The scenarios are considered fixed as the treatments included in the study were carefully selected and are the only treat- 
10 J. K. LADHA et al.

Table 6 Estimated environment-wise (site $\times$ year) scenario means of selected parameters based on annual aggregate system data using mixed model analysis

\begin{tabular}{|c|c|c|c|c|c|c|}
\hline Parameter & Site & Year & Scenario 1 & Scenario 2 & Scenario 3 & Scenario 4 \\
\hline \multirow[t]{8}{*}{ GEY } & \multirow[t]{2}{*}{ Ghazipur } & 1 & $135.94 \mathrm{c}$ & $168.73 \mathrm{~b}$ & $166.94 \mathrm{~b}$ & $270.66 \mathrm{a}$ \\
\hline & & 2 & $121.15 \mathrm{c}$ & $161.4 \mathrm{a}$ & $158.86 \mathrm{a}$ & $137.39 \mathrm{~b}$ \\
\hline & \multirow[t]{2}{*}{ Karnal } & 1 & $188.55 \mathrm{~b}$ & $214.69 \mathrm{a}$ & $195.33 \mathrm{~b}$ & $182.85 \mathrm{~b}$ \\
\hline & & 2 & 159.82 c & $189.74 \mathrm{~b}$ & $198 \mathrm{~b}$ & 209.35 a \\
\hline & \multirow[t]{2}{*}{ Patna } & 1 & $103.47 \mathrm{c}$ & $142.62 \mathrm{~b}$ & $144.33 \mathrm{~b}$ & 291.76 a \\
\hline & & 2 & $139.04 \mathrm{~d}$ & $183.41 \mathrm{c}$ & $230.51 \mathrm{~b}$ & $345.37 \mathrm{a}$ \\
\hline & \multirow{2}{*}{ Aduthurai } & 1 & $112.05 \mathrm{a}$ & $121.22 \mathrm{a}$ & $96.029 \mathrm{~b}$ & $64.130 \mathrm{c}$ \\
\hline & & 2 & $115.69 \mathrm{~b}$ & $170.6 \mathrm{a}$ & $138.88 \mathrm{ba}$ & $151.42 \mathrm{a}$ \\
\hline \multirow[t]{8}{*}{ NIC } & \multirow[t]{2}{*}{ Ghazipur } & 1 & $395.57 \mathrm{c}$ & $965.47 \mathrm{~b}$ & $1039.4 \mathrm{~b}$ & $1476.11 \mathrm{a}$ \\
\hline & & 2 & $336.16 \mathrm{c}$ & $739.33 \mathrm{ba}$ & $893.82 \mathrm{a}$ & 458.38 bc \\
\hline & \multirow[t]{2}{*}{ Karnal } & 1 & $1685.85 \mathrm{cb}$ & $2229.73 \mathrm{a}$ & $1892.95 \mathrm{~b}$ & $1633.91 \mathrm{c}$ \\
\hline & & 2 & $1355.74 \mathrm{c}$ & $1952.08 \mathrm{~b}$ & $2101.84 \mathrm{~b}$ & $2384.73 \mathrm{a}$ \\
\hline & \multirow[t]{2}{*}{ Patna } & 1 & $675.17 \mathrm{c}$ & $1725.67 \mathrm{~b}$ & $1883.67 \mathrm{~b}$ & $2856.33 \mathrm{a}$ \\
\hline & & 2 & $1481.90 \mathrm{~d}$ & $2834.73 \mathrm{c}$ & $3246.17 \mathrm{~b}$ & $4191.47 \mathrm{a}$ \\
\hline & \multirow[t]{2}{*}{ Aduthurai } & 1 & $897.63 \mathrm{ba}$ & $1176.98 \mathrm{a}$ & 491.92 b & $\mathrm{N} / \mathrm{A}$ \\
\hline & & 2 & 1081.96 c & $2697.31 \mathrm{a}$ & $1756.95 \mathrm{~b}$ & $1443.20 \mathrm{cb}$ \\
\hline \multirow[t]{8}{*}{ TWP } & \multirow[t]{2}{*}{ Ghazipur } & 1 & $6.54 \mathrm{c}$ & $9.47 \mathrm{~b}$ & $8.82 \mathrm{~b}$ & $27.35 \mathrm{a}$ \\
\hline & & 2 & $5.58 \mathrm{c}$ & $8.29 \mathrm{~b}$ & $7.95 \mathrm{~b}$ & $11.58 \mathrm{a}$ \\
\hline & \multirow[t]{2}{*}{ Karnal } & 1 & $6.01 \mathrm{~b}$ & $7.02 \mathrm{~b}$ & $7.03 \mathrm{~b}$ & $13.97 \mathrm{a}$ \\
\hline & & 2 & $4.80 \mathrm{~d}$ & $6.94 \mathrm{c}$ & $8.66 \mathrm{~b}$ & $16.36 \mathrm{a}$ \\
\hline & \multirow[t]{2}{*}{ Patna } & 1 & $7.27 \mathrm{c}$ & $9.65 \mathrm{~b}$ & $10.72 \mathrm{~b}$ & $17.87 \mathrm{a}$ \\
\hline & & 2 & $8.44 \mathrm{~d}$ & $10.93 \mathrm{c}$ & $14.63 \mathrm{~b}$ & 20.18 a \\
\hline & \multirow[t]{2}{*}{ Aduthurai } & 1 & $5.30 \mathrm{~b}$ & $6.74 \mathrm{a}$ & $5.23 \mathrm{~b}$ & $3.50 \mathrm{c}$ \\
\hline & & 2 & $\mathrm{~N} / \mathrm{A}$ & $\mathrm{N} / \mathrm{A}$ & $\mathrm{N} / \mathrm{A}$ & $\mathrm{N} / \mathrm{A}$ \\
\hline \multirow[t]{8}{*}{ PARCE } & \multirow[t]{2}{*}{ Ghazipur } & 1 & $1.34 \mathrm{c}$ & $1.83 \mathrm{~b}$ & $1.84 \mathrm{~b}$ & $2.64 \mathrm{a}$ \\
\hline & & 2 & $1.66 \mathrm{c}$ & $3.21 \mathrm{~b}$ & $3.41 \mathrm{~b}$ & $5.21 \mathrm{a}$ \\
\hline & \multirow[t]{2}{*}{ Karnal } & 1 & $2.43 \mathrm{~b}$ & $1.99 \mathrm{c}$ & $2.67 \mathrm{a}$ & $2.62 \mathrm{a}$ \\
\hline & & 2 & $2.17 \mathrm{cb}$ & $2.25 \mathrm{~b}$ & $2.02 \mathrm{c}$ & $2.57 \mathrm{a}$ \\
\hline & Patna & 1 & $1.8 \mathrm{c}$ & $1.69 \mathrm{c}$ & $2.22 \mathrm{~b}$ & $2.60 \mathrm{a}$ \\
\hline & & 2 & $2.2 \mathrm{c}$ & $2.07 \mathrm{c}$ & $3.57 \mathrm{a}$ & $2.35 \mathrm{~b}$ \\
\hline & Aduthurai & 1 & $1.32 \mathrm{~b}$ & $1.33 \mathrm{~b}$ & $1.41 \mathrm{~b}$ & $1.96 \mathrm{a}$ \\
\hline & & 2 & $1.1 \mathrm{~b}$ & $1.58 \mathrm{a}$ & $0.87 \mathrm{~b}$ & $1.77 \mathrm{a}$ \\
\hline PFPN & Ghazipur & 1 & $0.59 \mathrm{c}$ & $0.66 \mathrm{~b}$ & $0.66 \mathrm{~b}$ & $1.00 \mathrm{a}$ \\
\hline & & 2 & $0.54 \mathrm{a}$ & $0.55 \mathrm{a}$ & $0.54 \mathrm{a}$ & $0.48 \mathrm{~b}$ \\
\hline & Karnal & 1 & $0.57 \mathrm{cb}$ & $0.69 \mathrm{a}$ & $0.6 \mathrm{~b}$ & $0.55 c$ \\
\hline & & 2 & $0.48 \mathrm{~b}$ & $0.61 \mathrm{a}$ & $0.61 \mathrm{a}$ & $0.63 \mathrm{a}$ \\
\hline & Patna & 1 & $0.34 \mathrm{~d}$ & $0.6 \mathrm{~b}$ & $0.48 c$ & $0.69 \mathrm{a}$ \\
\hline & & 2 & $0.46 \mathrm{c}$ & $0.78 \mathrm{~b}$ & $0.77 \mathrm{~b}$ & $0.82 \mathrm{a}$ \\
\hline & Aduthurai & 1 & $0.37 \mathrm{c}$ & $0.64 \mathrm{a}$ & $0.51 \mathrm{~b}$ & $0.16 \mathrm{~d}$ \\
\hline & & 2 & $0.39 \mathrm{c}$ & $0.90 \mathrm{a}$ & $0.74 \mathrm{~b}$ & $0.38 \mathrm{c}$ \\
\hline LP & Ghazipur & 1 & $0.28 \mathrm{c}$ & $0.42 \mathrm{~b}$ & $0.43 \mathrm{~b}$ & $0.58 \mathrm{a}$ \\
\hline & & 2 & $0.32 \mathrm{c}$ & $0.45 \mathrm{~b}$ & $0.53 \mathrm{a}$ & $0.34 \mathrm{c}$ \\
\hline & Karnal & 1 & $2.46 \mathrm{c}$ & $2.28 \mathrm{c}$ & $3.61 \mathrm{a}$ & $2.92 \mathrm{~b}$ \\
\hline & & 2 & $1.91 \mathrm{c}$ & $2.25 \mathrm{~b}$ & $3.10 \mathrm{a}$ & $3.25 \mathrm{a}$ \\
\hline & Patna & 1 & $0.87 \mathrm{c}$ & $0.70 \mathrm{~d}$ & $1.62 \mathrm{a}$ & $1.22 \mathrm{~b}$ \\
\hline & & 2 & $1.17 \mathrm{~b}$ & $0.90 \mathrm{c}$ & $1.66 \mathrm{a}$ & $1.15 \mathrm{~b}$ \\
\hline & Aduthurai & 1 & $0.23 \mathrm{~b}$ & $0.27 \mathrm{a}$ & $0.25 \mathrm{ba}$ & $0.17 \mathrm{c}$ \\
\hline & & 2 & $0.24 \mathrm{~b}$ & $0.39 a$ & $0.35 \mathrm{a}$ & $0.41 \mathrm{a}$ \\
\hline NER & Ghazipur & 1 & $3.36 \mathrm{c}$ & $3.72 \mathrm{~b}$ & $3.81 \mathrm{~b}$ & $5.94 \mathrm{a}$ \\
\hline & & 2 & $2.85 \mathrm{c}$ & $3.47 \mathrm{a}$ & $3.20 \mathrm{~b}$ & $2.96 \mathrm{c}$ \\
\hline & Karnal & 1 & $2.70 \mathrm{c}$ & $3.92 \mathrm{~b}$ & $3.68 \mathrm{~b}$ & $5.24 \mathrm{a}$ \\
\hline & & 2 & $2.11 \mathrm{~d}$ & $3.23 c$ & $3.90 \mathrm{~b}$ & $5.81 \mathrm{a}$ \\
\hline & Patna & 1 & $1.90 \mathrm{~b}$ & $2.96 \mathrm{a}$ & $3.29 \mathrm{a}$ & $3.13 \mathrm{a}$ \\
\hline & & 2 & $2.76 \mathrm{c}$ & $4.09 \mathrm{~b}$ & $6.07 \mathrm{a}$ & $3.91 \mathrm{~b}$ \\
\hline
\end{tabular}


Table 6 (continued)

\begin{tabular}{|c|c|c|c|c|c|c|}
\hline Parameter & Site & Year & Scenario 1 & Scenario 2 & Scenario 3 & Scenario 4 \\
\hline & Aduthurai & 1 & $2.05 \mathrm{~b}$ & $3.38 \mathrm{a}$ & $0.92 \mathrm{c}$ & $0.46 \mathrm{~d}$ \\
\hline & & 2 & $1.59 \mathrm{~b}$ & $3.54 \mathrm{a}$ & $1.01 \mathrm{c}$ & $0.89 \mathrm{c}$ \\
\hline \multirow[t]{8}{*}{ GWPi } & Ghazipur & 1 & $0.14 \mathrm{a}$ & $0.13 \mathrm{a}$ & $0.12 \mathrm{~b}$ & $0.04 \mathrm{c}$ \\
\hline & & 2 & $0.14 \mathrm{ba}$ & $0.12 \mathrm{~b}$ & $0.14 \mathrm{a}$ & $0.13 \mathrm{ba}$ \\
\hline & Karnal & 1 & $0.08 \mathrm{a}$ & $0.07 \mathrm{~b}$ & $0.06 \mathrm{c}$ & $0.04 \mathrm{~d}$ \\
\hline & & 2 & $0.08 \mathrm{a}$ & $0.07 \mathrm{~b}$ & $0.05 \mathrm{c}$ & $0.03 \mathrm{~d}$ \\
\hline & Patna & 1 & $0.18 \mathrm{a}$ & $0.14 \mathrm{~b}$ & $0.09 \mathrm{c}$ & $0.05 \mathrm{~d}$ \\
\hline & & 2 & $0.17 \mathrm{a}$ & $0.13 b$ & $0.09 \mathrm{c}$ & $0.05 \mathrm{~d}$ \\
\hline & Aduthurai & 1 & $0.14 \mathrm{~b}$ & $0.12 \mathrm{~b}$ & $0.18 \mathrm{a}$ & $0.19 \mathrm{a}$ \\
\hline & & 2 & $0.19 \mathrm{a}$ & $0.10 \mathrm{ba}$ & $0.15 \mathrm{bc}$ & $0.08 \mathrm{c}$ \\
\hline
\end{tabular}

Refer to Tables 3 and 4 for scenario and parameter details. For each parameter, means followed by a common letter in a row are not significantly different at $5 \%$ level of significance. N/A indicates nonavailability.

ments of interest. The environments are modeled as a random sample from the 'target' population of environments (TPE). Therefore, environmental main effects and the scenario $x$ environment interaction effects were considered random. The analysis was performed using the MIXED procedure of SAS (Littell et al., 2006), which uses the Restricted Maximum Likelihood procedure to estimate the variance components. The scenario means are then regarded as means in the TPE. The scenario means across eight environments were standardized and the standardized means were plotted on spider charts to visualize the performances for a subset of the chosen input and the corresponding output parameters.

GGE mega-environment grouping. A GGE (genotype + genotype $\times$ environment) biplot analysis (Yan et al., 2000; Yan \& Kang, 2003) of GEY based on the environmentspecific scenario predicted means from the model Eqn (1) was performed. A two-dimensional environment-scaled GGE biplot graphically summarized the interrelationship among environments, scenarios, and interactions between scenarios and environments that exist in the original data. The responsive scenarios, termed vertex scenarios, are those farthest away from the origin of the biplot. These scenarios divided the biplot into three sectors and thus identified possible groups called mega-environments. Vertex scenarios without any environments (S1) in their respective sector were not the highest-yielding in any environment.

Crop rotation-wise analysis. The GGE biplots broadly classified the eight environments into two subgroups comprising of sites that belonged to the rice-rice and wheat-rice cropping systems. Scenarios were evaluated across environments within these subgroups using model Eqn (1).

Season-wise analysis. Apart from the environmental subgroups based on the scenario responses that were indicated by the biplots, the second approach to environmental classification was based on the available season-wise data (dry and wet season). These were subject to analysis using model Eqn (1) with the objective of obtaining the effects of scenarios across environments.

\section{Results}

\section{Performance of different management scenarios across environments}

Environment-wise scenario means for a chosen set of eight prime parameters (Table 6) show that S4 was among the top performers in most environments for GEY, TWP, PARCE and GWPi. Scenario 3 was best for labor productivity (LP), whereas S4 followed by S3 and S2 were good for NER and net income (NIC), respectively. Results of the combined analysis over locations and years with respect to various annual aggregate (dry, summer, and wet season crops) parameters [based on both per unit land area $\left(\mathrm{ha}^{-1}\right)$ and per unit food energy $\left(\mathrm{GJ}^{-1}\right)$ produced] demonstrated that scenarios responded differently to variations in environmental conditions indicated by a significant scenario $x$ environment variance component (Table 7). Scenario yield, averaged across environments, showed that farmers' management practice (S1) produced an annual yield of $9.29 \mathrm{Mg} \mathrm{ha}^{-1}$ (GY) or $9.61 \mathrm{GYRE}$, or $134 \mathrm{GJ} \mathrm{ha}^{-1}$ in terms of GEY. Scenario 4, which had BMPs and CA with diversified cropping, was the best performing scenario for GY, GYRE, and GEY. Adoption of S4 would result in 54\% higher GEY than S1. Despite significantly higher cost of cultivation $(42.0 \%$ higher on a per unit area basis [COST: US $\$ \mathrm{ha}^{-1}$ ] and $12.0 \%$ on a per unit food energy produced basis [GEE: US\$ $\mathrm{GJ}^{-1}$ ] in S4 than the average of S1-S3), the net economic return was higher (US\$ 2019) in S4 than in S1 (Table 8). Spider chart of the standardized means of each scenario for the chosen set of input parameters measured on per unit land area basis and output parameters based on per unit energy basis shown in Fig. 3. The lengths of the spokes are proportional to the magnitude of the parameter with longer spokes projecting outward for higher values. A higher cost of cultivation in S4 was 
Table 7 REML estimates for the annual system data based on combined analysis across environments (site $\times$ year) using mixed model analysis.

\begin{tabular}{|c|c|c|c|c|c|c|c|c|}
\hline \multirow[b]{2}{*}{ S. no } & \multirow[b]{2}{*}{ Parameter } & \multicolumn{3}{|c|}{ Variance components } & \multicolumn{4}{|c|}{$F$ test for scenario (S) } \\
\hline & & $S \times E$ & Error & $R($ no $)$ & Numdf & Den df & $F$ value (scenario) & $P$ value (scenario) \\
\hline 1. & $\mathrm{MCI}^{*}$ & & & & & & & \\
\hline 2. & GY & $35.33 \dagger$ & 0.76 & 3 & 3 & 21 & 5.71 & 0.0051 \\
\hline 3. & GYRE & $8.51 \dagger$ & 0.39 & 3 & 3 & 21 & 4.09 & 0.0196 \\
\hline 4. & GEY & $1888.42 \dagger$ & 76.59 & 3 & 3 & 21 & 3.65 & 0.0293 \\
\hline 5. & IWI & $152433 \dagger$ & 4270.03 & 3 & 3 & 18 & 5.26 & 0.0088 \\
\hline 6. & IWP & $153.96 \dagger$ & 5.23 & 3 & 3 & 18 & 9.25 & 0.0006 \\
\hline 7. & TWI & $165773 \dagger$ & 4325.04 & 3 & 3 & 18 & 4.71 & 0.0135 \\
\hline 8. & TWP & $5.72 \dagger$ & 0.29 & 3 & 3 & 18 & 15.28 & 0.0000 \\
\hline 9. & PARi* & & & & & & & \\
\hline 10. & PARCE & $0.3602 \uparrow$ & 0.01 & 3 & 3 & 21 & 3.92 & 0.0228 \\
\hline 11. & $\mathrm{NI}^{*}$ & & & & & & & \\
\hline 12. & PFP-N & $0.02 \dagger$ & 0 & 3 & 3 & 21 & 3.14 & 0.0467 \\
\hline 13. & $R I^{*}$ & & & & & & & \\
\hline 14. & $\mathrm{LI}^{*}$ & & & & & & & \\
\hline 15. & LP & $0.085 \dagger$ & 0 & 3 & 3 & 21 & 5.57 & 0.0057 \\
\hline 16. & EI & $208.59 \dagger$ & 1.3 & 3 & 3 & 21 & 1.57 & 0.2260 \\
\hline 17. & NER & $0.74 \dagger$ & 0.05 & 3 & 3 & 21 & 4.99 & 0.0090 \\
\hline 18. & COST & $186628 \dagger$ & 682.94 & 3 & 3 & 21 & 6.02 & 0.004 \\
\hline 19. & GEE & $12.83 \dagger$ & 0.82 & 3 & 3 & 21 & 2.32 & 0.1044 \\
\hline 20. & NIC & $239875 \dagger$ & 36841 & 3 & 3 & 20 & 6.06 & 0.0042 \\
\hline 21. & GEP & $2.09 \dagger$ & 0.76 & 3 & 3 & 20 & 7.14 & 0.0019 \\
\hline 22. & GWP† & & & & & & & \\
\hline 23. & GWPi & $0.00079 \dagger$ & 0 & 3 & 3 & 21 & 6.91 & 0.0020 \\
\hline
\end{tabular}

Refer Table 4 for parameter details.

*Parameters had same replicate values.

$\dagger$ Model simulated value.

due to greater cropping intensity [310\% multiple cropping intensity in S4 compared with $275 \%$ in S2 and S3 and $200 \%$ in S1] in this scenario which offset savings in reduced or no tillage operation. The conversion of photosynthetically active solar radiation (PARCE: GJ GJ $J^{-1} \times 100$ ) in S4 was $58.1 \%$ higher than in S1 indicating the possibility of enhancing PARCE through improvement in management practices besides genetic crop improvement. Despite the highest incident photosynthetically active radiation (PARi: GJ ha ${ }^{-1}$ ), the substitution of rice and wheat with potato or maize in S4 also resulted in an increasing PARCE. This was likely due to a combination of high cropping intensity, the $\mathrm{C}_{4}$ nature of maize and an overall superior crop performance. The harvest index for many crops is approaching a ceiling value and hence an increase in genetic yield potential necessitates an increase in crop biomass (Evans, 2013) by improving canopy photosynthetic assimilation rate and radiation conversion efficiency (Horton, 2000; Evans, 2013). The amount of irrigation water input (IWI: $\mathrm{mm} \mathrm{ha}^{-1}$ ) was appreciably lower for S4 $(60.6 \%$ lower than S1 and 51.6\% lower than S2), while its yield per unit of water input (IWP: $G J \mathrm{~m}^{3}$ ) was remarkably higher $(247.8 \%$ higher than S1 and $129.5 \%$ higher than S2). Total water input (TWI: $\mathrm{mm} \mathrm{ha}{ }^{-1}$ ) in S4 was significantly less (35\% lower than S1 and 28\% lower than S2), while water productivity (TWP: Gj $\mathrm{m}^{3}$ water) more than doubled, from $6.28 \mathrm{GJ}$ GEY $\mathrm{m}^{3}$ water in $\mathrm{S} 1$ to $14.64 \mathrm{GJ}$ GEY $\mathrm{m}^{3}$ water in $\mathrm{S} 4$. The over exploitation of groundwater by agriculture for irrigation during recent years has lowered aquifer levels in many Asian countries, and pumping water from lower strata in the future would result in a greater use of energy, which is mostly generated by coal combustion, and would therefore results in increased emissions of GHG (Zhang et al., 2013). Improved water use efficiency is likely to become a critical criterion for many grain-producing areas in South Asia, in part due to necessary adaptation to the anticipated adverse effects from climate change (Elliott et al., 2014). Increasing the $\mathrm{N}$ use efficiency of the cropping system has always been a priority because of concerns about the escalating cost of fertilizer and the environmental footprint associated with large losses of $\mathrm{N}$ and the high 
Table 8 Estimated means of annual aggregate system data based on mixed model analysis

\begin{tabular}{|c|c|c|c|c|c|}
\hline S. no. & Parameter* & Scenario $1^{*}$ & Scenario 2 & Scenario 3 & Scenario 4 \\
\hline 1. & Multiple cropping index $-\mathrm{MCI}(\%) \dagger$ & 225 & 275 & 275 & 310 \\
\hline 2. & Grain yield - GY $\left(\mathrm{Mg} \mathrm{ha}^{-1}\right) \ddagger$ & $9.29 \mathrm{~b}$ & $11.70 \mathrm{~b}$ & $11.50 \mathrm{~b}$ & $20.68 \mathrm{a}$ \\
\hline 3. & Grain yield rice equivalent - GYRE $\left(\mathrm{Mg} \mathrm{ha}^{-1}\right) \ddagger$ & $9.61 \mathrm{~b}$ & $13.19 \mathrm{a}$ & $11.87 \mathrm{ab}$ & $14.54 \mathrm{a}$ \\
\hline 4. & Grain energy yield (output) - GEY (GJ ha $\left.{ }^{-1}\right) \ddagger$ & $134 \mathrm{~b}$ & $169 \mathrm{ab}$ & $166 \mathrm{ab}$ & $207 \mathrm{a}$ \\
\hline 5. & Irrigation water input - IWI $\left(\mathrm{mm} \mathrm{ha}^{-1}\right)$ & $1342 \mathrm{a}$ & $1094 \mathrm{a}$ & $980 \mathrm{a}$ & $529 \mathrm{~b}$ \\
\hline 6. & Irrigation water productivity - IWP (GJ m³) & $13.25 \mathrm{~b}$ & $20.08 \mathrm{~b}$ & $21.68 \mathrm{~b}$ & $46.08 \mathrm{a}$ \\
\hline 7. & Total (irrigation + rain) water input - TWI $\left(\mathrm{mm} \mathrm{ha}^{-1}\right)$ & $2274 \mathrm{a}$ & $2071 \mathrm{a}$ & 1962 a & $1484 \mathrm{~b}$ \\
\hline 8. & Total (irrigation + rain) water productivity $-\mathrm{TWP}\left(\mathrm{GJ} \mathrm{m}^{3}\right)$ & $6.28 \mathrm{c}$ & $8.44 \mathrm{bc}$ & $9.01 \mathrm{~b}$ & $14.64 \mathrm{a}$ \\
\hline 9. & $\begin{array}{l}\text { Photosynthetically active radiation incident - PARi } \\
\left(\mathrm{GJ} \mathrm{ha} \mathrm{h}^{-1}\right) \dagger\end{array}$ & 135 & 169 & 166 & 206 \\
\hline 10. & $\begin{array}{l}\text { Photosynthetically active radiation conversion } \\
\text { efficiency - PARCE }\left(G J G^{-1} \times 100\right)\end{array}$ & $1.72 \mathrm{~b}$ & $2.25 \mathrm{ab}$ & $2.03 \mathrm{~b}$ & 2.73 a \\
\hline 11. & Nitrogen fertilizer input - NI $\left(\mathrm{kg} \mathrm{ha}^{-1}\right) \dagger$ & 290 & 253 & 272 & 351 \\
\hline 12. & Partial factor productivity of $\mathrm{N}-\mathrm{PFP}-\mathrm{N}\left(\mathrm{GJ} \mathrm{kg} \mathrm{N} \mathrm{kg}^{-1}\right)$ & $0.47 \mathrm{~b}$ & $0.68 \mathrm{a}$ & $0.61 \mathrm{ab}$ & $0.59 \mathrm{ab}$ \\
\hline 13. & Residue input - RI $\left(\mathrm{Mg} \mathrm{ha}^{-1}\right) \dagger$ & 0.65 & 5.02 & 8.39 & 12.44 \\
\hline 14. & Labor input - LI (person-days ha $\left.{ }^{-1}\right) \dagger$ & 278 & 280 & 228 & 312 \\
\hline 15. & Labor productivity - LP (GJ day $\left.{ }^{-1}\right)$ & $0.93 \mathrm{~b}$ & $0.96 \mathrm{~b}$ & $1.44 \mathrm{a}$ & $1.23 \mathrm{ab}$ \\
\hline 16. & Energy input - EI (GJ ha $\left.{ }^{-1}\right)$ & $55 \mathrm{a}$ & $45 \mathrm{a}$ & $43 \mathrm{a}$ & $56 \mathrm{a}$ \\
\hline 17. & Net energy ratio - NER (GJ GJ ${ }^{-1}$ ) & $2.50 \mathrm{~b}$ & $3.84 \mathrm{a}$ & $3.93 \mathrm{a}$ & $3.82 \mathrm{a}$ \\
\hline 18. & Cultivation cost - COST (US\$ ha $\left.{ }^{-1}\right)$ & $1736 \mathrm{~b}$ & $1836 \mathrm{~b}$ & $1624 \mathrm{~b}$ & 2461 a \\
\hline 19. & Grain energy expenditure - GEE (US\$ GJ ${ }^{-1}$ ) & $13.33 \mathrm{ab}$ & $11.26 \mathrm{ab}$ & $10.64 \mathrm{~b}$ & $14.89 \mathrm{a}$ \\
\hline 20. & Net income - NIC (US\$ ha ${ }^{-1}$ ) & $990 \mathrm{~b}$ & $1814 \mathrm{a}$ & 1677 a & 2019 a \\
\hline 21. & Grain energy profit - GEP (US\$ GJ ${ }^{-1}$ ) & $7.17 \mathrm{c}$ & $10.50 \mathrm{a}$ & $9.61 \mathrm{ab}$ & $8.41 \mathrm{bc}$ \\
\hline 22. & Global warming potential - GWP $\left(\mathrm{kg} \mathrm{CO}_{2} \mathrm{eq} \mathrm{ha}^{-1}\right) \S$ & 8641 & 8411 & 8389 & 8030 \\
\hline 23. & $\begin{array}{l}\text { Global warming potential intensity - GWPi } \\
\left(\mathrm{kg} \mathrm{CO}_{2} \mathrm{eq} \mathrm{MJ}^{-1}\right)\end{array}$ & $0.1425 \mathrm{a}$ & $0.1142 \mathrm{~b}$ & $0.1112 \mathrm{ab}$ & 0.0762 c \\
\hline
\end{tabular}

For each parameter, means followed by a common letter in are not significantly different at $5 \%$ level of significance.

${ }^{*}$ Refer to Table 3 for scenario details and Table 4 for parameter details.

$\uparrow$ Values in replicates do not differ.

†rain yield refers to tuber yield in case of potato.

$\S$ Model simulated values.

energy demand and GWP of synthetic N production. Increases in the partial factor productivity of fertilizer $\mathrm{N}$ (PFP-N) of $44.7 \%, 29.8 \%$, and $25.5 \%$ in S2, S3, and S4, respectively, over $\mathrm{S} 1$ indicate large potential for increasing crop productivity and $\mathrm{N}$ use efficiency and thus reducing GWP. The energy balance was highly positive in $\mathrm{S} 2, \mathrm{~S} 3$, and S4 as shown by an average increase of $54.5 \%$ in net energy ratio (NER) in these scenarios from that of $2.5 \mathrm{GJ} \mathrm{GJ}^{-1}$ in $\mathrm{S} 1$ to $3.84,3.93$, and $3.82 \mathrm{GJ} \mathrm{GJ}^{-1}$ in S2, S3 and S4, respectively. Fossil fuel energy plays a key role in food security and development. As current food production and energy use patterns cannot be sustained if global climate change targets are to be met, enhancing energy use efficiency is paramount (FAO, 2012). Scenario 3 with optimal mechanization was the best in terms of LP. Scenario 3 had 54.8\% higher LP than S1 and S2, primarily because of shifting from rice transplanting to direct- (or drill-) seeding. This improvement in LP was not at the expense of an increase in fossil fuel energy. The growth rate of the labor force in Asian agriculture declined from $0.73 \%$ per year during 1990-2000 to $0.36 \%$ per year during 2000-2013 (FAOSTAT, 2014). Thus, the adoption of labor-saving practices as in S3 is imminent, in view of fast-increasing labor shortages and labor wages that are threatening agriculture globally and in South Asia in particular.

In addition to the mixed model evaluation of the scenarios with respect to the performance indicators, the 'technical efficiency' or the maximum outputs possible from given inputs of the four scenarios were determined using a stochastic production frontier model (Coelli et al., 1998; Kumbhakar \& Lovell, 2000). The stochastic frontier regression analysis suggests that S3 and S4 have technical efficiencies that are consistently and statistically higher than S1 (R. Rejesus, J.K. Ladha, A. Raman and A.N. Rao, unpublished). However, S3 had the highest mean technical efficiency compared to all the other scenarios. Although S4 tends to have the highest yields, this scenario also generally used more 

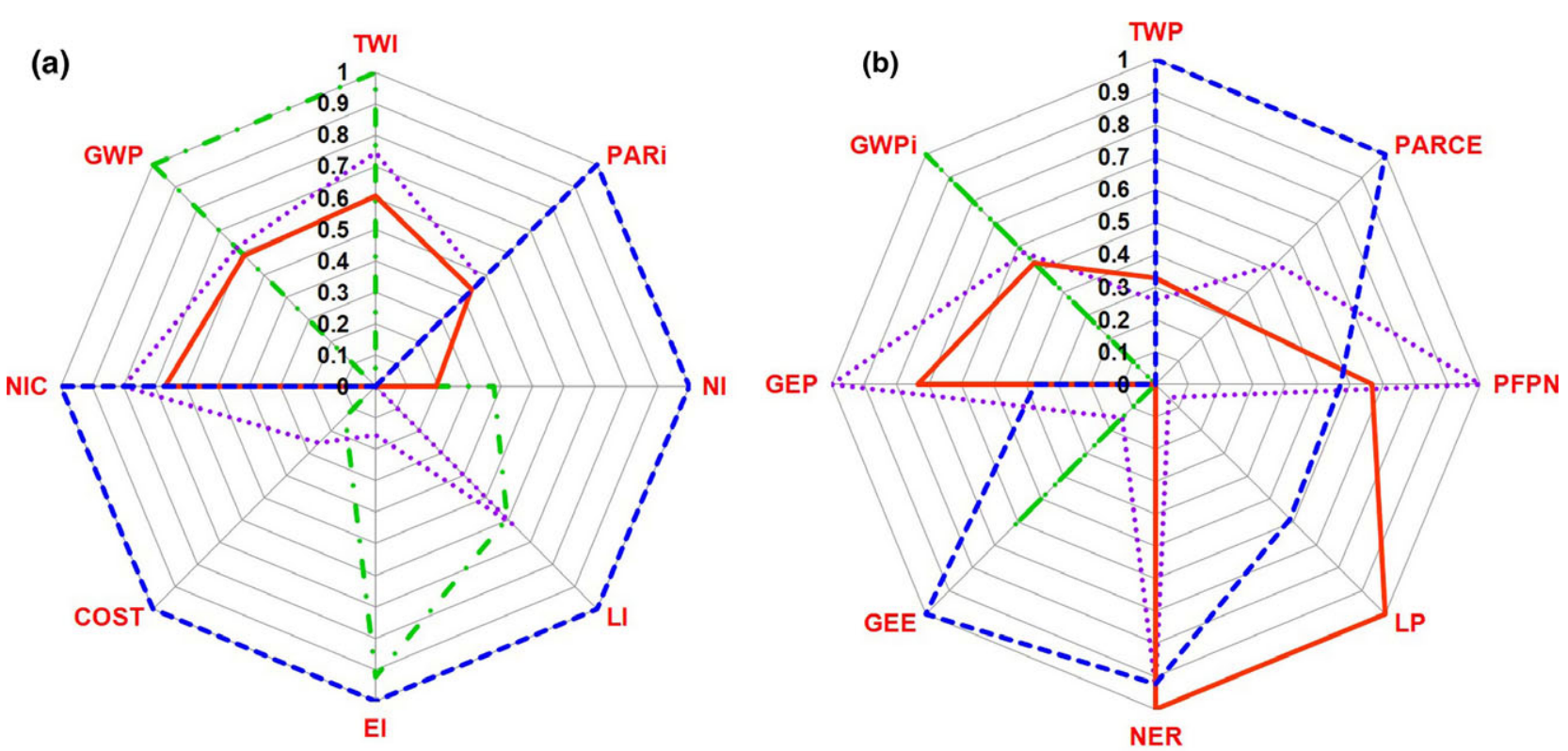

- Scenario 1

...... Scenario 2

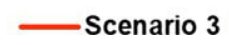

- - Scenario 4

Fig. 3 Spider chart showing standardized means of scenarios estimated for the chosen set of performance indicators using mixed model from annual aggregate data of four scenarios: (a) expressed on per unit area basis $\left(\mathrm{kg} \mathrm{ha}^{-1}\right)$ and (b) expressed on per unit (MJ or GJ) food produced. Replicates of the following parameters do not differ: photosynthetically active radiation incident (PARi), nitrogen fertilizer input (NI), and labor input (LI). Global warming potential (GWP) values are model simulated; higher GWP values indicate negative impact. Refer to Table 8 for actual average values. TWI, total water input; EI, energy input; COST, cultivation cost; NIC, net income; TWP, total water productivity; PFP-N, partial factor productivity of N; LP, labor productivity; NER, net energy ratio; GWPi, global warming potential intensity; GEE, grain energy expenditure; GEP, grain energy profit.

inputs than the other scenarios. Hence, the S3 is more technically efficient as it utilized the available inputs better than other scenarios. Regardless of this specific observation, the technical efficiency analysis revealed that all of the three improved scenarios (S2-S4) clearly outperform the control 'business-as-usual' scenario (S1; R. Rejesus, personal communication).

The gross GWP based on GHG emissions $\left(\mathrm{CH}_{4}\right.$ and $\mathrm{N}_{2} \mathrm{O}$ using the factors of 25 and 298, respectively, relative to $\mathrm{CO}_{2}$ over a 100 -year time horizon) and that associated with various inputs used during the cropping period (fuel, electricity, fertilizer, herbicide, and pesticide) was calculated in different scenarios (S1-S4). Total GWP ( $\mathrm{kg} \mathrm{CO}_{2}$ ) on a per unit area (ha) basis remained the same but, when scaled against GEY, GWPi $\left(\mathrm{CO}_{2}\right.$ eq $\mathrm{MJ}^{-1}$ ) differed significantly among the four scenarios (Table 8). Scenario 4 had a GWPi of $0.08 \mathrm{~kg} \mathrm{CO}$ eq $\mathrm{MJ}^{-1}$, which was significantly lower than the $0.14 \mathrm{~kg}$ $\mathrm{CO}_{2}$ eq $\mathrm{MJ}^{-1}$ in $\mathrm{S} 1$ and $0.11 \mathrm{~kg} \mathrm{CO}_{2}$ eq MJ ${ }^{-1}$ in $\mathrm{S} 2$ and S3. Our results confirm earlier conclusions based on GHG emissions in rice that improving crop yields with efficient use of resources addresses concerns regarding both food demand and climate change (Pittelkow et al., 2014a). Emissions of $\mathrm{CH}_{4}$ and $\mathrm{N}_{2} \mathrm{O}$ from soil during cereal cultivation contributed to $46 \%$ of total GHG emis- sions. Other major sources of emissions were electricity used for irrigation (30\%) and $\mathrm{N}$ fertilization (17\%). Of the total annual GWPi of $0.14 \mathrm{~kg} \mathrm{CO}_{2}$ eq MJ ${ }^{-1}$ in S1, rice contributed $55 \%$ and the remaining came from wheat. Rice cultivation is a major source of $\mathrm{CH}_{4}$, currently accounting for 10-15\% of all global GHG emissions from agriculture and $10-12 \%$ of the world's total anthropogenic $\mathrm{CH}_{4}$ emissions (IPCC, 2014). Tillage moisture and aeration, and $\mathrm{C}$ supply affect $\mathrm{CH}_{4}$ emissions (Wassmann et al., 2000; Venterea et al., 2005; Jiao et al., 2007). The management practices such as AWD involved in alternative rice land preparation and crop establishment in the improved scenarios (S3-S4) in the present study were reported to cause lower methane emissions from rice paddies (Adhya et al., 2014; Linquist et al., 2015). However, as different factors interact and the magnitude of interactions results in temporal and spatial variability in emissions of $\mathrm{CH}_{4}$, it is not possible to estimate a relative effect of any single factor. Land use change and emission reduction in agriculture will be key elements in achieving an $80 \%$ reduction in GHG emissions by 2050 (Rockström et al., 2013). A significant reduction in GWPi in S4 suggests that in areas where cropping system diversification is feasible there is also scope for mitigation of GHG emissions in the 


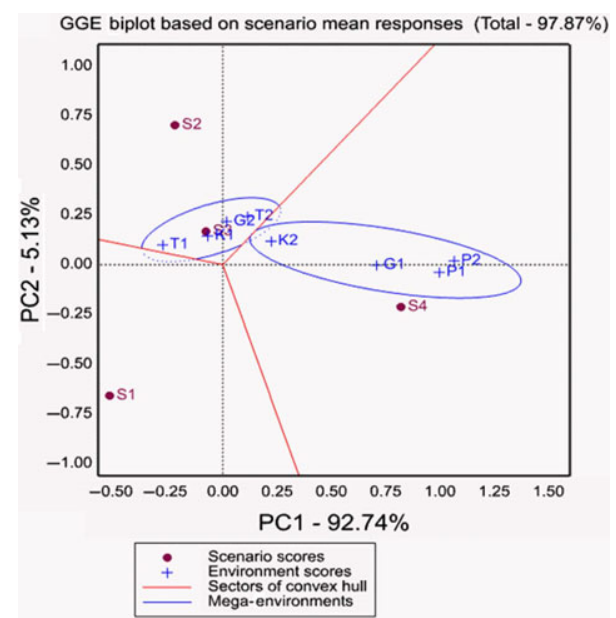

Fig. 4 Best performing environments for each of the tested scenarios. Biplot $(G+G \times E$ : genotype + genotype $\times$ environment $)$ showing wheat-rice and rice-rice mega-environments and the responsive scenarios. Environment (site $\times$ year)-specific means estimated from mixed model were used to generate the biplots. (Mega-environments indicated by ellipse).

rice-based ecosystem, while enhancing crop production.

\section{Differential response of $C A$ in crop rotations and seasons}

The biplot analysis based on the scenario responses to GEY broadly showed two groups of environments and identified the most appropriate scenarios for each (Fig. 4). Scenario 4 with CA and crop diversification performed best in wheat-rice agro-ecosystems, and S2 with CA only in dry-season crops without diversification was best in rice-rice agro-ecosystems. A combined analysis of environments within each group showed that in wheat-rice, GEY increased by $23.6 \%$ in S2, by $30.0 \%$ in S3, and increased to $74.2 \%$ in S4, as compared with S1, whereas in rice-rice GEY increased by $28.2 \%$ in S2 but remained unchanged across scenarios (Table 9). Mean performances of other key parameters such as NIC, TWP, PARCE, NER, and GWPi showed that $\mathrm{S} 4$ was significantly superior in the wheat-rice system whereas S2 did well in the rice-rice system but was not always significantly different from other scenarios. Further, analysis across environments within each season using the available season-wise data also showed that, during the dry season, S4 outperformed S2 in terms of prime parameters (GEY, NIC, TWP, and PARCE), whereas, during the wet season, S2 was favorable for most parameters but did not significantly differ from other scenarios (Table 10). This indicated that the wheat-rice rotation, in which wheat or other upland crops substituting wheat are grown in the dry season, tends to respond to two principles of $\mathrm{CA}$; conservation tillage and residue soil cover. On the other hand, the rice-rice rotation in which rice is traditionally grown in the wet season under puddled wetlands, conservation tillage and residue cover may not always be feasible and hence would not respond.

\section{High crop productivity and high economic returns are possible with low GWPi}

Aggregate and seasonal means of S4 indicated that high productivity GEY and high economic returns (NIC) are possible with reduced GWPi (Fig. 5). To investigate a possible generalization of this trend across other scenarios, GEY and NIC (dual $y$-axis) were plotted against GWPi ( $x$-axis) across the environments and scenarios. Scatter plots showed that both GEY $\left(r=-0.786^{*}\right)$ and NIC $\left(r=-0.603^{*}\right)$ were inversely proportional to GWPi (Fig. 5). This suggests that targeting high productivity through BMPs including relevant CA components and crop diversification will lead to high economic returns coupled with reduced environmental footprints. This is in contradiction with a widely held belief that high crop productivity is not possible without compromising on the environment and economics (Bakari, 2014; Norton et al., 2015).

\section{Discussion}

In Asia, the Green Revolution resulted in high growth rates of food grain production, which by and large kept pace with population growth until recently. However, beginning in the late 1980s, annual crop productivity growth rates started to slow in many of the typical Green Revolution regions, despite the increasing use of inputs (labor, water, and agro-chemicals) (Byerlee \& Murgai, 2001; Cassman et al., 2003). Although there seems to be a general consensus that significant potential exists to produce enough food to meet the future demand (Dobermann et al., 2013), opinions differ on how this should be accomplished and whether it can be achieved economically and without compromising on the resource base and environmental integrity (Foley et al., 2011; Tilman et al., 2011). As there is minimal scope for expanding land under cultivation in Asia without causing unacceptable environmental damage (Bruinsma, 2011), growth in crop production must be through increased crop productivity, crop diversification, and improved efficiency in resource usage. Our results provide strong experimental evidence that, with best agronomic practices, including CA practices and crop diversification, the productivity of rice- and wheat-based cropping systems of South Asia can be increased, in combination with positive economic 


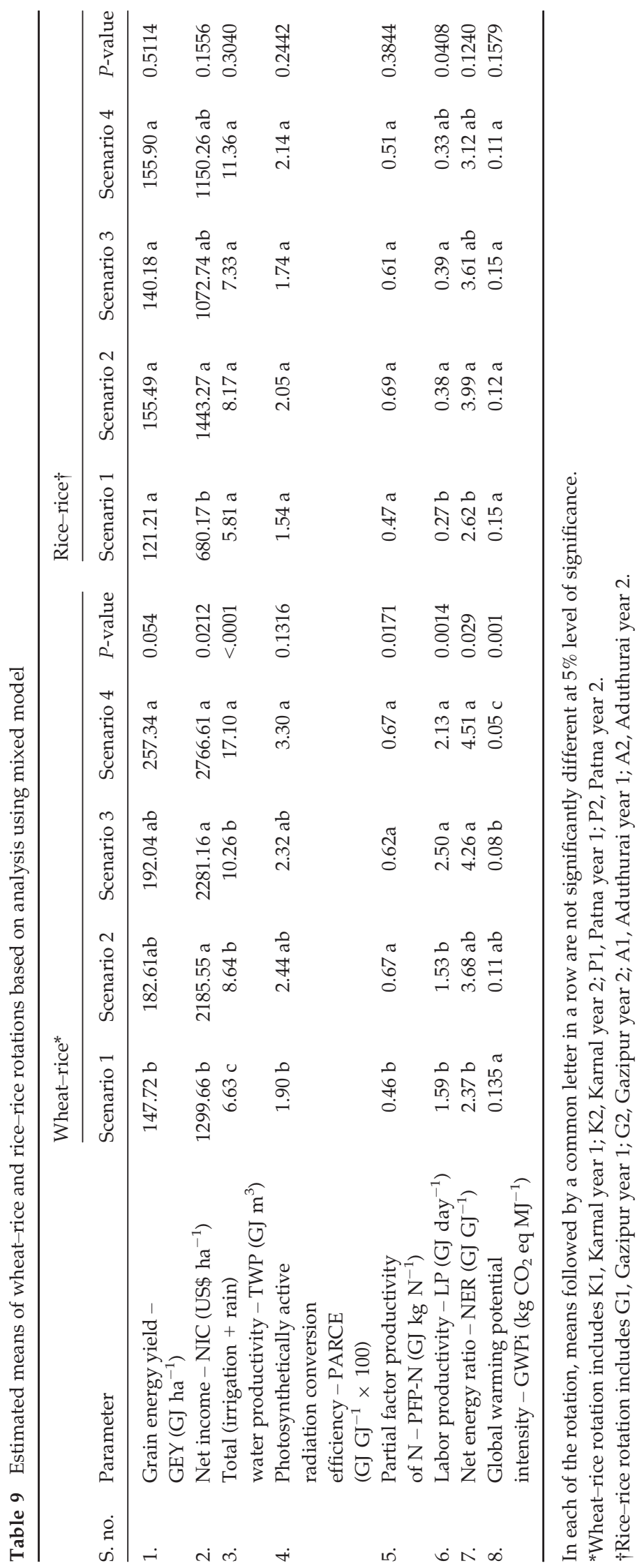




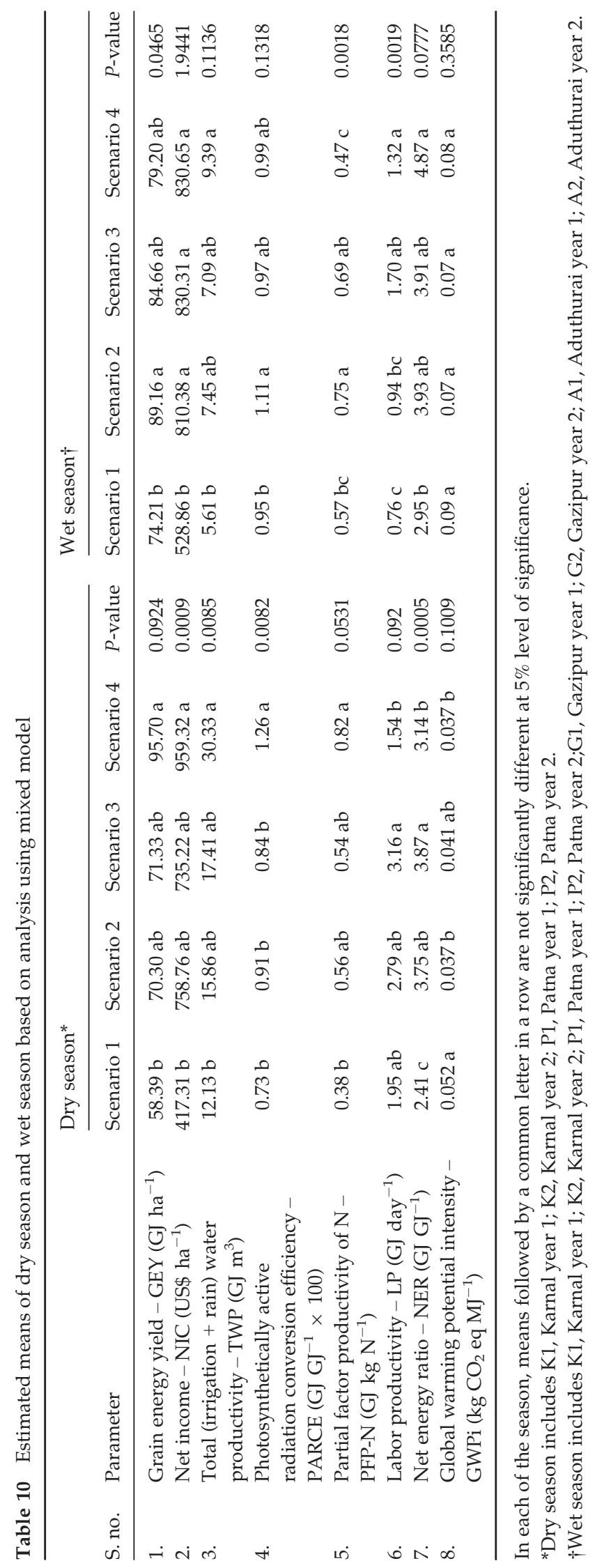




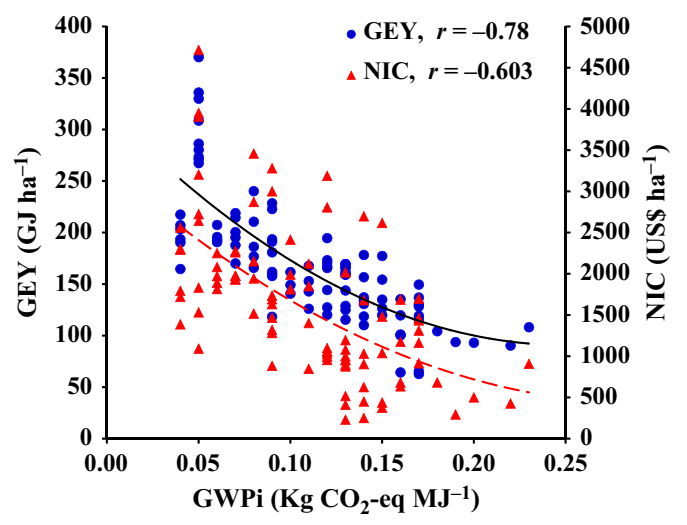

Fig. 5 Scatter plots of grain energy yield (GEY) and net income (NIC) plotted against global warming potential intensity (GWPi) across environments and scenarios.

returns; less use of water, labor, N, and fossil fuel energy per unit food produced, and thus also a lower GWPi. Our study evaluated integrated systems solutions of CA and other BMPs in different scenarios (S2-S4). It was therefore not feasible to quantify the benefits from a particular practice. While various components are likely to contribute incrementally, integration of additional crops in a rotation, mechanization, dry direct seeding or unpuddled transplanting of rice, and crop based $\mathrm{N}$ management are likely to have contributed most to overall system productivity and efficiency. An overall superiority of S4 strongly suggests that CA with crop diversification is likely to be successful in rice-upland crop growing environments, particularly on approximately 25 million ha in South Asia and China where upland crops such as wheat are already grown in rotation with rice. The comprehensive baseline dataset generated in the present study will allow the prediction of benefits at a larger scale through appropriate models, although long-term effects of the different management scenarios remain to be studied. Similar results of producing more grain with less environmental impact have recently been demonstrated for wellmanaged maize production systems in the United States (Grassini \& Cassman, 2012) and intensive cereal systems in China (Shen et al., 2013; Chen et al., 2014).

Although CA has attracted widespread attention among scientists, farmers, and policy makers, the benefits of its adoption are not as clear cut in all situations. Recently, a meta-analysis of global data evaluated the impact of CA components on grain yields of diverse crops under different agro-ecosystems (Pittelkow et al., 2014b). The results revealed that adoption of all three components of CA resulted in a $2.5 \%$ loss of grain yield on average. The negative impact on yield increased if no-till was implemented alone $(-9.9 \%)$ or with only one other CA component being adopted $(-5.2 \%$ and $-6.2 \%$ for residue retention and crop rotation, respectively). However, this study did not consider the impacts of CA on economic returns or input use efficiencies but admitted that there could be other positive effects (Pittelkow et al., 2014b). Our experiments showed that, in the first two years of implementing a diversified cropping with CA-based crop and management systems (S3 and S4), high crop production benefits were achieved. Significant increases in productivity were also recorded with the adoption of zero or reduced tillage and residue cover in only dry-season crops in rotation in S2. Equally important were the significant positive benefits of increased economic returns and efficiencies of inputs (water, solar radiation, fertilizer N, labor, fossil fuel energy), and lower GWPi, which were also achieved in S2. Another notable finding of this study is the differential response of CA observed in different cropping seasons and crop rotations. Crops grown in the dry season (or in a wheat-rice rotation) responded better to CA practices than crops grown in the wet season (or in a rice-rice rotation). When compared with farmers' conventional tillage, CA practices have been reported to result in a greater availability of water to the crop due to increased water infiltration and lower evaporation with reduced mixing of the surface soil, more residue cover, and less exposure of soil to drying (Palm et al., 2014). Thus, the higher soil moisture retention throughout the growing season with CA (Thierfelder et al., 2013) explains the greater response of dry-season crops to CA as observed in our study. On the other hand, in lowlands where soils remain submerged because of monsoon rains, CA components, especially no-till and residue retention, have not always worked (Alam et al., 2015). Because of this reason, most often, the practice of all three CA components (zero or reduced tillage, soil cover using crop residues, and crop rotations) in their totality is not feasible and therefore often not all CA components are integrated in farmers' existing management portfolios in all crop rotations and locations. Practical and site-specific approaches as compared to the strict implementation of CA principles were inevitable in order to protect the soil health, to enhance crop response as well as ensure productivity (Kirkegaard et al., 2014). This highlights the need for characterizing area suitable for different CA components and subsequent technology targeting.

Crop residues have many competing uses notably animal feed, other off-site use, and a significant amount is burned on-farm. Therefore, there may be a concern that if crop residue is widely used on soil surface as advocated in CA, it may happen at the expense of its 
use as fodder (Erenstein et al. 2007). On the other hand, burning of crop residue in the field is considered as the most cost-effective way of its disposal which, however, results in environmental pollution (Gadde et al., 2009). If we can avoid large scale burning of residue and divert its use in fields as mulch, we may be able to strike a right balance between its dual use as fodder and soil amendment. Residue mulch is critical and has to be combined with conservation tillage for maximizing and sustaining the beneficial effects of CA.

\section{Limitations}

The experiments were conducted over two years across four locations that adequately represent the agro-ecological conditions, cropping systems, and farming practices. Short-term multi-environment trials (METs) such as this focus on the initial orientation to the crop management scenarios, the initial environmental limiting factors and their interactions with the scenarios (Jaradat, 2013). It should also be noted that, in METs each additional environment involves additional cost and resources. The analysis of METs often assumes that the sites are a random sample of all possible sites in the region and years being a random set of future years (Yang, 2010; Piepho et al., 2011). The process of data analysis should always account for the random or fixed nature of the different factors and, if the experimental design includes both types of effects, a mixed model approach should be followed (Onofri et al., 2010). The utility of mixed models to obtain best possible estimates of the fixed and random effects in the analysis of MET data has been demonstrated earlier (Crossa, 1990; Yang, 2008). Some comparisons among scenarios that may be significant in a single-environment analysis may not be significant in a combined analysis over environments. However, the objectives of these two analyses are substantially different. In a single-environment trial, the focus would be on the performances in the individual environments, whereas the joint analysis with random environments is much more ambitious as it treats the test environments as a sample from the whole TPE. The applicability of the results to larger-scale ecosystem services (e.g., impact on water levels, biodiversity etc.) needs to be investigated further. It also remains to be seen whether the performance of the four systems studied will change significantly over time, positively or negatively (Gathala et al., 2011a,b; Jat et al., 2014). Time varying technical efficiency of the systems also needs to be evaluated. Impacts on soil quality may differ among the systems and sites (Gathala et al., 2011a; Powlson et al., 2014). New issues such as control of weeds, diseases, and insects may emerge. Only planned long-term studies of the present kind can evaluate the agronomic stability and resilience of crop diversification and CA practices. This requires repeated measurements on the same plots in order to assess the year to year variability. Another potential limitation of our study is the simulation of GHG measurements at two of four locations, and only in two main crops. Our observations indicate that the simulations were identical to those measured and thus validate the procedure followed in the experimentation. Likewise lack of GHG measurements in the summer crops likely to have underestimated the total GWP though overall impact of GHG was relatively lower than those associated with the energy inputs. Nevertheless, the initial results are promising and many of the BMPs and CA practices included in our scenarios are already being evaluated and further finetuned in thousands of farmers' fields in the region, through CSISA (http://csisa.org/), STRASA (Stress Tolerant Rice for Africa and South Asia http:/ /strasa.irri.org/) and other initiatives. We believe that the framework along with a set of performance criteria with baseline values generated in this study will be a valuable resource for developing extrapolation domains for an effective ecological intensification program in the major cropping systems in Asia. Simultaneously, there is a need to initiate a new generation of long-term studies at multiple locations representing key agro-ecosystems to establish the sustainability of intensification.

\section{Acknowledgments}

This research was funded by the Bill \& Melinda Gates Foundation (BMGF), the United States Agency for International Development (USAID) and the Global Rice Science Partnership (GRiSP) of the CGIAR, through the CSISA. We are grateful to the Soil Salinity Research Institute (CSSRI), Karnal; the Indian Council of Agricultural Research Complex for Eastern Region (ICAR-RCER), Patna; Tamil Nadu Rice Research Institute (Tamil Nadu Agricultural University), Aduthurai; Bangladesh Rice Research Institute (BRRI), Gazipur; and Bangladesh Agricultural Research Institute (BARI), Gazipur, for providing staff, experimental land and other key inputs for the conduct of the experimental platforms. We thank Dr. Bill Hardy for editing the manuscript.

\section{References}

Adhya TK, Linquist B, Searchinger T, Wassmann R, Yan X. (2014) Wetting and drying: reducing greenhouse gas emissions and saving water from rice production. Installment 8 of Creating a Sustainable Food Future, pp. 1-28. World Resources Institute, Washington, DC.

Alam MM, Ladha JK, Faisal MW et al. (2015) Improvement of cereal based cropping systems with best management practices following the principle of conservation agriculture under changing agricultural scenarios in Bangladesh. Field Crops Research, 175, 1-15.

Alexandratos N, Bruinsma J (2012) World agriculture towards 2030/2050: the 2012 revision. ESA Working paper No. 12-03, pp. 1-147. FAO, Rome, Italy.

Audsley E, Stacey K, Parsons DJ, Williams AG (2009) Estimation of the Greenhouse Gas Emissions from Agricultural Pesticide Manufacture and Use, pp. 1-20. Cranfield University, Bedford, UK. 
Bakari M (2014) Sustainability's inner conflicts: from 'ecologism' to 'ecological modernization'. Journal of Sustainable Development Studies, 6, 1-28.

Balasubramanian V, Adhya TK, Ladha JK (2012) Eco-efficiency: from vision to reality. Enhancing eco-efficiency in the intensive cereal-based systems of the Indo-Gangetic Plains. Issues in Tropical Agriculture - Eco-Efficiency: From Vision to Reality, pp. 1 7. CIAT Publication, Cali, CO.

Balwinder-Singh, Humphreys E, Eberbach PL, Katupitiya A, Yadvinder-Singh, Kukal SS (2011) Growth, yield and water productivity of zero till wheat as affected by rice straw mulch and irrigation schedule. Field Crops Research, 121, 209-225.

Brouder SM, Gomez-Macpherson H (2014) The impact of conservation agriculture on smallholder agricultural yields: a scoping review of the evidence. Agriculture, Ecosystems \& Environment, 187, 11-32.

Bruinsma J (2011) The resource outlook to 2050: by how much do land, water use and crop yields need to increase by 2050?. In: Looking Ahead in World Food and Agriculture: Perspectives to 2050 (ed. Conforti P), pp. 233-278. FAO, Rome, Italy.

Byerlee D, Murgai R (2001) Sense and sensibility revisited. Agricultural Ecology, 26, 227-236.

Cassman KG, Dobermann A, Walters DT, Yang HS (2003) Meeting cereal demand while protecting natural resources and improving environmental quality. Annual Reviews of Environmental Research, 28, 315-358.

CFT (2014) The Cool Farm Tool Version 2.0 beta 3. Copyright (C) 2014. Cool Farm Alliance.

Chen X, Cui Z, Fan M et al. (2014) Producing more grain with lower environmental costs. Nature, 514, 486-489.

Coelli TJ, Prasada Rao DS, Battese GE (1998) An Introduction to Efficiency and Productivity Analysis, pp. 241-261. Kluwer Academic Publishers, Boston, Dordrecht, London

Crossa J (1990) Statistical analyses of multilocation trials. Advances in Agronomy, 44, 55-85.

Dobermann A, Witt C, Dawe D (2004). Increasing Productivity of Intensive Rice Systems through Site-Specific Nutrient Management, pp. 1-410. Science Publishers, Inc., Enfield, N.H., USA and International Rice Research Institute, Los Baños, Philippines.

Dobermann A, Nelson R, Beever D et al. (2013) Solutions for sustainable agriculture and food systems. Technical Report for the Post-2015 Development Agenda, pp. 1-99. Sustainable Development Solutions Network, New York, www.unsdsn.org.

Elliott J, Deryng D, Muller C et al. (2014) Constraints and potentials of future irrigation water availability on agricultural production under climate change. Proceed ings of the National Academy of Science, 111, 3239-3244.

Erenstein O, Thorpe W, Singh J, Varma A (2007) Crop-livestock Interactions and Livelihoods in the Indo-Gangetic Plains, India. Crop-livestock Interactions Scoping Study Syntheses, CIMMYT-RWC, New Delhi, India.

Erenstein O, Laxmi V (2008) Zero tillage impacts in India's rice-wheat systems: a review. Soil Tillage Research, 100, 1-14.

Evans JR (2013) Improving photosynthesis. Plant Physiology, 162, 1780-1793.

FAO (2012) Energy Smart Food at FAO. An Overview, pp. 1-71. FAO, Rome, Italy

FAOSTAT (2014) FAO online statistical database on agricultural labor force. FAO, Rome, Italy. Available at: http://faostat3.fao.org/home/E (accessed 12 July 2014).

Foley JA, Ramankutty N, Brauman KA et al. (2011) Solutions for a cultivated planet. Nature, 478, 337-342.

Gadde B, Bonnet S, Menke C, Garivait S (2009) Air pollutant emissions from rice straw open field burning in India, Thailand and the Philippines. Environmental Pollution, 157, 1554-1558.

Gathala MK, Ladha JK, Vivak Kumar et al. (2011a) Effect of tillage and crop establishment methods on physical properties of a medium-textured soil under 7-year ricewheat rotation. Soil Science Society of America Journal, 75, 1851-1862.

Gathala MK, Ladha JK, Vivak Kumar et al. (2011b) Tillage and crop establishment affects sustainability of South Asian rice-wheat system. Agronomy Journal, 103, 961-971.

Gathala MK, Kumar V, Sharma PC et al. (2013) Optimizing intensive cereal-based cropping systems addressing current and future drivers of agricultural change in the north-western Indo-Gangetic plains of India. Agriculture, Ecosystems \& Environment, 177, 85-97.

Gopalan C, Sastri BVR, Balasubramanian SC (1978) Nutritive Value of Indian Foods. National Institute of Nutrition, Indian Council of Medical Research, Hyderabad, India.

Grassini P, Cassman KG (2012) High-yield maize with large net energy yield and small global warming intensity. Proceedings of the National Academy of Science, 109, 1074-1079.

Gupta RK, Naresh RK, Hobbs PR, Jiaguo J, Ladha JK (2003). Sustainability of postgreen revolution agriculture: the rice-wheat cropping systems of the Indo-Gange- tic Plains and China. In: Improving the Productivity and Sustainability of Rice-Wheat Systems: Issues and Impact (eds Ladha JK, Hill J, Gupta RK, Duxbury J, Buresh RJ), pp. 1-25. ASA Special Publication 65, Madison, WI, USA.

Harrington LW, Hobbs PR (2009) The rice-wheat consortium and the Asian development bank: a history. In: Integrated Crop and Resource Management in the Rice-Wheat System of South Asia (eds Ladha JK, Yadvinder-Singh, Erenstein O, Hardy B), pp. 3-68. International Rice Research Institute (IRRI), Los Baños, Philippines.

Hobbs PR, Gupta R, Sayre K (2008) The role of conservation agriculture in sustainable agriculture. Philosophical Transactions of the Royal Society. Biological Science, 363, 543-555.

Horton P (2000) Prospects for crop improvement through the genetic manipulation of photosynthesis: morphological and biochemical aspects of light capture. Journal of Experimental Botany, 51, 475-485.

Institute for the Study of Earth, Oceans and Space (ISEOS) (2009) User's Guide for the DNDC. Model Version 9.3, University of New Hampshire, NH.

IPCC (2014) Climate change 2014: mitigation of climate change. In: Contribution of Working Group III to the 5th AR of the IPCC (eds Edenhofer O et al. ), pp. 1-1435. Cambridge University Press, Cambridge, United Kingdom and New York, NY, USA.

Jaradat AA (2013) Covariance structures in conventional and organic cropping systems. International Journal of Agronomy, 2013, 1-8.

Jat RK, Sapkota TB, Singh RG et al. (2014) Seven years of conservation agriculture in a rice-wheat rotation of Eastern Gangetic Plains of South Asia: yield trends and economic profitability. Field Crops Research, 164, 199-210.

Jiao Z, Hou A, Shi Y, Huang G, Wang Y, Chen X (2007) Water management influencing methane and nitrous oxide emissions from rice field in relation to soil redox and microbial community. Communications in Soil Science and Plant Analysis, 37, 1889-1903.

Khurana HS, Phillips SB, Bijay Singh et al. (2008) Agronomic and economic evaluation of site-specific nutrient management for irrigated wheat in northwest India. Nutrient Cycling in Agroecosystem, 82, 15-31.

Kirkegaard JA, Conyers MK, Hunt JR, Kirkby CA, Watt M, Rebetzke GJ (2014) Sense and nonsense in conservation agriculture: principles, pragmatism and productivity in Australian mixed farming systems. Agriculture, Ecosystems \& Environment, 187, 133-145.

Kumar V, Ladha JK (2011) Direct seeding of rice: recent developments and future research needs. Advances in Agronomy, 111, 297-413.

Kumar V, Saharawat Y, Gathala MK et al. (2013) Effect of different tillage and seeding methods on energy use efficiency and productivity of wheat in the Indo-Gangetic Plains. Field Crops Research, 142, 1-8.

Kumbhakar SC, Lovell CAK (2000) Stochastic Frontier Analysis. Cambridge University Press, UK.

Ladha JK, Hill JE, Duxbury JD, Gupta RK, Buresh RJ (2003) Improving the Productivity and Sustainability of Rice-Wheat Systems: Issues and Impact. American Society of Agronomy Spec. Publ. 65, ASA, CSSA, SSSA, Madison, WI, USA.

Ladha JK, Bhushan L, Gupta RK et al. (2009) Performance of integrated crop and resource management technologies in the rice-wheat system in South Asia. In: Integrated Crop and Resource Management Technologies for Sustainable Rice-Wheat Systems of South Asia (eds Ladha JK, Singh Y, Erenstein O), pp. 69-108. International Rice Research Institute, Manila, Philippines.

Laik R, Sharma S, Idris M et al. (2014) Integration of conservation agriculture with best management practices for improving system performance of the rice-wheat rotation in the Eastern Indo-Gangetic plains of India. Agriculture, Ecosystems $\mathcal{E}$ Environment, 195, 68-82.

Li C, Frolking S, Frolking TA (1992a) A model of nitrous oxide evolution from soil driven by rainfall events: 1 . Model structure and sensitivity. Journal of Geophysical Research, 97, 9759-9776.

Li C, Frolking S, Frolking TA (1992b) A model of nitrous oxide evolution from soil driven by rainfall events: 2. Applications. Journal of Geophysical Research, 97, 97779783.

Li C, Frolking S, Harriss RC (1994) Modeling carbon biogeochemistry in agricultural soils. Global Biogeochemical Cycles, 8, 237-254.

Linquist BA, Anders MM, Adviento-Borbe MAA, Chaney RL, Nalley LL, da Rosa EFF, van Kessel C (2015) Reducing greenhouse gas emissions, water use, and grain arsenic levels in rice systems. Global Change Biology, 21, 407-417.

Littell RC, Milliken GA, Stroup WW, Wolfinger RD, Schabenberger O (2006) SAS for Mixed Models (2nd edn), pp. 1-814. SAS Institute Inc., Cary, NC.

Norton GW, Alwang J, Masters WA (2015) Economics of Agricultural Development: World Food Systems and Resource Use. Routledge, New York, USA.

Onofri A, Carbonell EA, Piepho HP, Mortimer AM, Cousens RD (2010) Current statistical issues in weed research. Weed Research, 50, 5-24. 
Palm C, Blanco-Canquib H, DeClerckc F, Gaterea L, Grace P (2014) Conservation agriculture and ecosystem services: An overview. Agriculture, Ecosystems \& Environment, 187, 87-105.

Pasuquin JM, Pampolino MF, Witt C et al. (2014) Closing yield gaps in maize production in Southeast Asia through site-specific nutrient management. Field Crops Research, 156, 219-230.

Piepho HP, Richter C, Spilke J et al. (2011) Statistical aspects of on-farm experimentation. Crop and Pasture Science, 62, 721-735.

Pittelkow CM, Adviento-Borbe MA, Kessel CV, Hill JE, Linquist BA (2014a) Optimizing rice yields while minimizing yield-scaled global warming potential. Global Change Biology, 20, 1382-1393.

Pittelkow CM, Xinqiang Liang, Linquist BA et al. (2014b) Productivity limits and potentials of the principles of conservation agriculture. Nature, 517, 365-368.

Powlson DS, Stirling CM, Jat ML et al. (2014) Limited potential of no-till agriculture for climate change mitigation. Nature Climate Change, 4, 678-683.

Prochnow LI, Cantarella H (2015) Modifying soil to improve crop productivity. Better Crops, 99, 10-12.

Rockström J, Sachs JD, Öhman MC, Schmidt-Traub G (2013) Sustainable Development and Planetary Boundaries. Thematic Group on Agroeconomics, Population Dynamics, and Planetary Boundaries, Background research paper prepared by the co-chairs of the Sustainable Development Solutions Network. High Level Panel on the Post-2015 Development Agenda (UN).

Shahin S, Jafai A, Mobli H, Rafiee S, Karini M (2008) Effect of farm size on energy ration on wheat production: a case study from Ardabil province of Iran. AmericanEurasian Journal of Agricultural \& Environmental Science, 3, 604-608.

Shen J, Zhenling Cui, Yuxin Miao et al. (2013) Transforming agriculture in China: from solely high yield to both high yield and high resource use efficiency. Global Food Security, 2, 1-8.

Singh B, Ryan J (2015) Managing Fertilizers to Enhance Soil Health. 24p. International Fertilizer Industry Association, 28, rue Marbeuf, 75008 Paris, France.

Singh S, Ladha JK, Gupta RK, Bhushan L, Rao AN, Sivaprasad B, Singh PP (2007) Evaluation of mulching, intercropping with Sesbania and herbicide use for weed management in dry-seeded rice (Oryza sativa L.). Crop Protection, 26, 518-524
Thierfelder C, Chisui JL, Gama M et al. (2013) Maize-based conservation agriculture systems in Malawi: long-term trends in productivity. Field Crops Research, 142, 47 57.

Tilman D, Balzer C, Hill J, Befort BL (2011) Global food demand and the sustainable intensification of agriculture. Proceedings of the National Academy of Science, USA, 108, 20260-20264.

Tirol-Padre A, Munmum Rai, Gathala MK et al. (2014) Assessing the performance of the photo-acoustic infrared gas monitor for measuring $\mathrm{CO}_{2}, \mathrm{~N}_{2} \mathrm{O}$, and $\mathrm{CH}_{4}$ fluxes in two major cereal rotations. Global Change Biology, 20, 287-299.

USEIA Energy Information Administration (2011) Fuel Emission Factors. Available at http://www.eia.gov/oiaf/1605/emission_factors.html (accessed 28 April 2011).

Venterea RT, Burger M, Spoka KT (2005) Nitrogen oxide and methane emissions under varying tillage and fertilizer management. Journal of Environmental Quality, 34, 1467-1477.

Verhulst N, Sayre KD, Vargas M, Crossa J, Deckers J, Raes D (2011) Wheat yield and tillage-straw management system $x$ year interaction explained by climatic co-variables for an irrigated bed planting system in northwestern Mexico. Field Crops Research, 124, 347-356.

Wassmann R, Neue HU, Lantin RS, Buendia LV, Rennenberg H (2000) Characterization of methane emissions from rice fields in Asia. I. Comparison among field sites in five countries. Nutrient Cycling in Agroecosystems, 58, 1-12.

Yan W, Kang MS (2003) GGE biplot analysis: a graphical tool for breeders, geneticists, and agronomists. CRC Press, Boca Raton.

Yan W, Hunt LA, Sheng Q, Szlavnics Z (2000) Cultivar evaluation and mega-environment investigation based on the GGE biplot. Crop Science, 40, 597-605.

Yang RC (2008) Why is MIXED analysis underutilized? Canadian Journal of Plant Sciences, 88, 563-567.

Yang RC (2010) Towards understanding and use of mixed-model analysis of agricultural experiments. Canadian Journal of Plant Sciences, 90, 605-627.

Yadvinder-Singh, Bijay-Singh, Timsina J (2005) Crop residue management for nutrient cycling and improving soil productivity in rice-based cropping systems in the tropics. Advances in Agronomy, 85, 269-407.

Zhang FS, Chen XP, Vitousek P (2013) Chinese agriculture: an experiment for the world. Nature, 497, 33-35. 